Algal Research

June 2016, Volume 16, Pages 418-426

http://dx.doi.org/10.1016/j.algal.2016.04.011

http://archimer.ifremer.fr/doc/00326/43737/

(c) 2016 Published by Elsevier Ltd.

\title{
Bacterial community structure of the marine diatom Haslea ostrearia
}

\author{
Lepinay Alexandra ${ }^{1,2}$, Capiaux Hervé ${ }^{3}$, Turpin Vincent ${ }^{1}$, Mondeguer Florence ${ }^{4}$, Lebeau Thierry ${ }^{2,{ }^{*}}$
}

${ }^{1}$ MMS EA 2160, Faculté des Sciences et des Techniques, Université de Nantes, 2 rue de la Houssinière, BP 92208, 44322 Nantes Cedex, France

${ }^{2}$ UMR LPGN 6112 CNRS, Université de Nantes, 2 rue de la Houssinière, BP 92208, 44322 Nantes

Cedex, France

${ }^{3}$ Plateforme d'Analyse Moléculaire Biodiversité-Environnement, IUT Dépt. Génie Biologique, 18

boulevard Gaston Defferre, 85035 La Roche-sur-Yon, France

${ }^{4}$ IFREMER, Laboratoire Phycotoxines, rue de l'île d'Yeu, 44311 Nantes Cedex 03, France

${ }^{*}$ Corresponding author : Thierry Lebeau,

\begin{abstract}
:
Haslea ostrearia produces a water-soluble, blue-green pigment, called marennine, with proven economic benefits (as a bioactive compound used to green oysters, which improves their market value). Incomplete knowledge of the ecological features of this marine diatom complicates its cultivation. More specifically, the ecology of bacteria surrounding $\mathrm{H}$. ostrearia in ponds is what remains unknown. The structure of this bacterial community was previously analyzed by means of PCR-TTGE before and after isolating $\mathrm{H}$. ostrearia cells recovered from 4 localities in order to distinguish the relative parts of the biotope and biocenose and to describe the temporal dynamics of the bacterial community structure at two time scales (2 weeks vs. 9 months). The bacterial structure of the phycosphere differed strongly from that of bulk sediment. The level of similarity between bacteria recovered from the biofilm and suspended bacteria did not exceed $10 \%$. On the other hand, similarities among the bacterial community structures in biofilms were above $90 \%$ regardless of the geographic origin of the algal isolates, while the percentages were lower for suspended bacteria. The differences in bacterial structures of two $\mathrm{H}$. ostrearia isolates (HO-R and $\mathrm{HO}-\mathrm{BM}$ ) resulted in specific metabolomic profiles. The nontargeted metabolomic investigation revealed more distinct profiles in the case of this bacteria-alga association than for the $\mathrm{H}$. ostrearia monoculture. At the culture cycle scale under laboratory conditions, the bacterial community depended on the growth stage. When $\mathrm{H}$. ostrearia was subcultured for 9 months, a shift in the bacterial structure was observed as of 3 months, with the bacterial structure stabilizing afterwards $(70 \%-86 \%$ similarities), in spite of the size reduction of the $\mathrm{H}$. ostrearia frustule. Based on these results, an initial insight into the relationships between $\mathrm{H}$. ostrearia and its surrounding bacteria could be drawn, leading to a better understanding of the ecological feature of this marine diatom.
\end{abstract}

Keywords : Biofilm, Ecology, Metabolic fingerprinting, Microalgae, Phycosphere, TTGE 
Haslea ostrearia is a cosmopolitan species of diatoms commonly found on the French Atlantic eөstcoast, especially in oyster ponds of the Bay of Marennes-Oléron and Bay of Bourgneuf [1]. This diatom has long been the subject of curiosity [2] and became a topic of

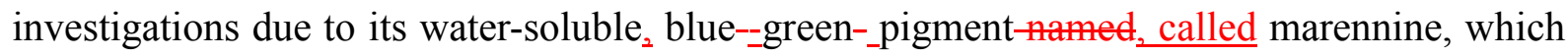
is responsible for the greening of oysters. This blue--green pigment ${ }_{2}$ produced duringwhen $H$. ostrearia blooms ${ }_{2}$ is released into the seawater, andat which point the ponds turn green._At this stage, $H$. ostrearia is the dominant diatom species in ponds, and oyster farmers use-take advantage of this phenomenon inby immersing their oysters in these shallow waters for 'refinement' (fattening) and greening, becausesince these last two final-stages of rearing are a raising oysters guarantee of the product quality and improve theira farm's profits. Beyond its interestbenefit in aquaculture for the greening-of oysters [3], it was demonstrated that marennine hadhas been shown to possess several biological functions with potential biotechnological applications, namely: i) antibacterial, anticoagulant and antiviral activities $[4,5]$,$] ; ii) antioxidant activity [6]]; and iii) antitumor and antiproliferative effects of the$ aqueous extract from $H$. ostrearia againston solid tumors (lung and kidney carcinoma and melanoma cell lines molecule).. But up to date, theline molecules). Until now however, an incomplete knowledge of the ecological conditions under which this microalgae develops in its natural ecosystem makehas complicated controlling the cultivation of $H$. ostrearia-difficult to control although, even though dedicated photobioreactors adapted to the physiological specificity of this microalga - by using- through the use of artificially immobilized cells -were designed at the laboratory scale $[7,8,9,-10]$. Indeed thisThis microalga indeed exhibits several behaviours mainlytypes of behavior, primarily benthic, occasionally planktonic- but also epiphytic [11, 12]], thus making immobilization a relevant. Ecophysiology course of action. The ecophysiology of $H$. ostrearia is complex and moreover not yet completely 
understood-as well. In oyster ponds, $H$. ostrearia can outcompete other microalgae butyet is also being consumed by oysters $[13,14,-15]$. The biotope of $H$. ostrearia wasbiotope has also been studied. It; it was demonstrated that: i) that this diatom has a high degree of toleranceis $\underline{\text { extremely tolerant to high irradiance, and-_thus offering an ecological advantage enover the }}$ other main diatoms encountered in oyster-_ponds, such ase.g. Skeletonema costatum [16, 17f]); and ii) that the greening phenomenon is controlled by the nutrient composition in oyster-pondspond waters,- (see [18] for conditions-[18].). Recently, a more detailed genetic characterization of $H$. ostrearia was undertaken with the development ofby developing genetic molecular tools and $_{2}$ which led to identifying new strains of $H$. ostrearia were identified [19] andalong with a second species of blue diatom namedcalled Haslea karadagensis.

Yet surprisingly, Surprisingly, only a few studies have focused on bacteria-microalgae interactions, while -in noting that some bacteria may increase the microalgal biomass with eonsequentlywhile offering potential applications in aquacultures. Up to dateaquaculture. For now, nothing is still known for the specific case of $H$. ostrearia, whileyet for instanceinstances regarding bacteria and diatoms, "overall, "they have co-occurred in common habitats throughout the oceans for more than 200 million years, fostering interactions between these two groups over evolutionary time scales"르. [20]. The link between bacterioplankton and phytoplankton dynamics was recently demonstrated by Rooney-Varga and colleagueset al. [21]. The habitat of phytoplankton-associated bacteria has been depicted by the "concept of "phycosphere" concept,", i.e.,. the area around algal cells where bacteria feed on extracellular products of the algae [22]. The phycosphere is thus the aquatic analog of the rhizosphere in soil ecosystems and has direct implications for nutrient fluxes to and from algal cells. The bacteriaBacteria-microalgae interactions werehave been studied for few diatomsseveral diatom species-such as, including Guinardia delicatula, Pseudonitizschia 
pugens, Thalassiosira rotula, Skeletonema costatum [23], Ditylum sp., Thalassiosira sp.,

102 Asterionella sp., Chaetoceros sp., Leptocylindrus sp., Coscinodiscus sp. [24], Pseudonitzschia multiseries [25],] and Nitzschia microcephala [26]. Some of these common species are frequently encountered in oyster-pond waters and sediments $[11,18]$. Overallon the whole, the bacterial biodiversity of the phycosphere was shown to be low when comparedlimited in comparison to the complexity of bacterial assemblages in bulk seawater [24]. The structure of the bacterial community linkedrelated to microalgae is at least-specific to the microalgae species $[20,24,27\}$ except], though some bacterial phylotypes, such as bacteroides, are known to haveplay a significant role in nutrient cycling through degradation efby degrading algal macromolecules-and for its attached; moreover, such species attach to growth and are then recovered in most phycospheres [28]. To demonstrate this specific bacterial-algal interaction, Schäfer and colleagueset al. [24] attempted, using two algal cultures, to associate each eneculture with the "“"satellite" ${ }_{-}$- bacterial assemblage of the other and showed that it was unfeasibleculture and proved such an association infeasible.

Based on these considerations, i.e., the. an incomplete knowledge of the ecological features of H. ostrearia, thisthe present work has been intended to: i) characterize the structure of the bacterial community by means of PCR-TTGE both before and after $H$. ostrearia isolation from oyster ponds efin different localities $\bar{j}_{2}$ ii) compare the bacterial community of the $\underline{H}$. ostrearia phycosphere of $H$. ostrearia-vs. free-_cells inwithin the culture medium ${ }_{;}$iii) distinguish the relative partportion of the biotope and the-biocenose based on the eomposition of the-bacterial structure composition; and iv) describe the temporal dynamic of the structure

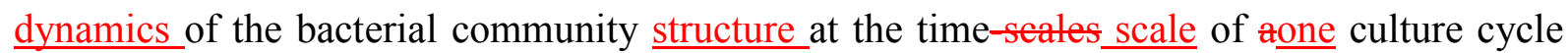
inunder laboratory conditions and after several subculturing steps. A metabolic fingerprinting (untargeted approach) was aimed to assessat assessing the global metabolic profile of $H$. 
ostrearia cultures, whether or not associated or not-with the bacteria of the phycosphere bacteria. Additional clarifications on the bacteria- $H$. ostrearia associations were provided-and, as well as on the role of the geographieatgeographic origin of $H$. ostrearia. Class(es) of The compound(s) being_class or classes potentially affected under the studiedthese study conditions were not anticipated-and; moreover, specific compounds were not necessarily identified or quantified.

\section{MateriałMaterials and methods}

SamplesThe test samples were collected in oyster ponds infrom four localities efalong the French Atlantic eost according to a North-Southcoast, along the following north-to-south gradient: Bouin $\left(46.96^{\circ} \mathrm{N} ; 2.04^{\circ} \mathrm{W}\right)$, La Barre-de-Monts $\left(46.90 \mathrm{~N} ; 2.11^{\circ} \mathrm{W}\right)$, Isle of Ré isłand $\left.\left(46.22 \mathrm{~N} ; 1.45^{\circ} \mathrm{W}\right)\right)_{2}$ and La Tremblade $\left(45.80 \mathrm{~N} ; 1.15^{\circ} \mathrm{W}\right)$ (see Fig._1). One liter of each sample was collected at the seawater-sediment interface, at on the bottom of the oyster ponds in order to haveobtain both sediment and seawater. Samplesthe samples were immediately stored at $4-{ }^{\circ} \mathrm{C}$. At In the laboratory, the presence of $H$. ostrearia was checkedverified before isolation. 


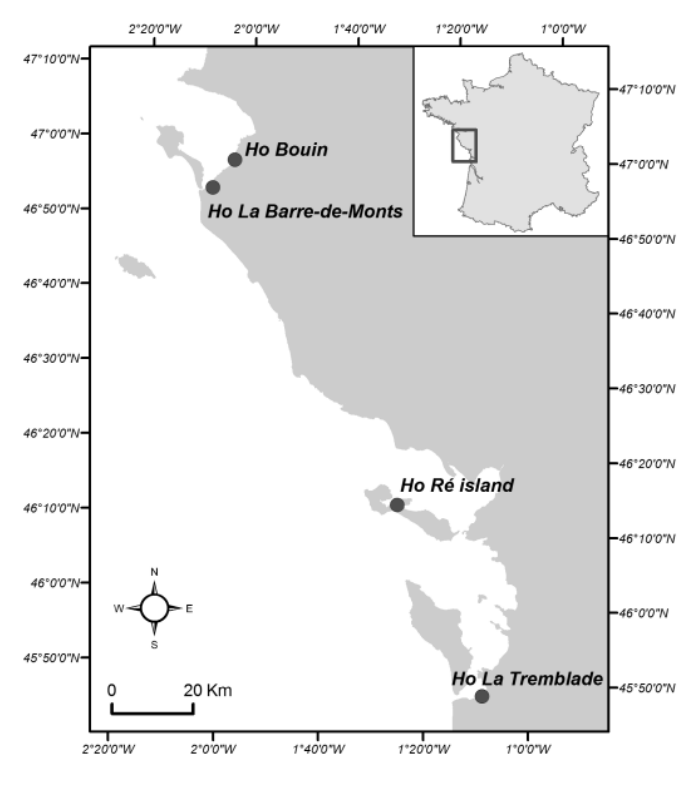

Fig. 1:: Map of the French Atlantic eostcoast showing oyster ponds localities-pond locations where samples were collected for isolation ofto isolate Haslea ostrearia: Bouin $\left(46.96^{\circ} \mathrm{N} ; 2.04^{\circ} \mathrm{W}\right), \mathrm{La}$ Barre-de-Monts $\left(46.90 \mathrm{~N} ; 2.11^{\circ} \mathrm{W}\right)$, Isle of Ré istand $\left.\left(46.22 \mathrm{~N} ; 1.45^{\circ} \mathrm{W}\right)\right)_{2}$ and La Tremblade $\left(45.80 \mathrm{~N} ; 1.15^{\circ} \mathrm{W}\right)$.

\section{2. -Isolation of $\boldsymbol{H}$. ostrearia from environmental samples and cultivation}

Monospecific cultures of $H$. ostrearia were obtained by isolation ofisolating a single cell of $H$. ostrearia from the raw samples. using and an inverted microscope, and; it was then washed by successive cell subculturing in filtered seawater $(0.22 \mu \mathrm{m})$ to remove contaminants (e.g.,, bacteria, other microalga, flagellate, larvae). Among the H. ostrearia isolates, six of them-were selected for the following studystudies: $\mathrm{HO} 1$ and HO2 Bouin (HO1-B and HO2-B), HO La Barre-de-Monts (HO-BM), HO Isle of Ré istand-(HO-R), and HO1 and HO2 La Tremblade (HO1-T and HO2$\mathrm{T})$.

For the followingensuing experiments, the above mentionedaforementioned isolates were grown in $250 \mathrm{~mL}$-Erlenmeyer flasks filled with $150 \mathrm{ml}$ of the modified Provasoli [29] medium (ES1/3: [30]) to obtain enoughsufficient biomass. The monospecific isolates of $H$. 
ostrearia were transferred atduring the exponential growth stage (every 7-10 days) ininto a fresh ES $1 / 3$ medium. CulturesThe cultures were incubated in a culture chamber at $16-{ }^{\circ} \mathrm{C}$ under $120 \mu \mathrm{mol}$ photons $\mathrm{m}^{-2} \mathrm{~s}^{-1}$ and $\underline{\text { a }}$ 14:10 h light_: dark regime.

\section{3. -Algal fingerprints and structure of the bacterial community structure}

\subsubsection{Sample preparation}

Raw sediments: The seawater and the-sediment of the raw samples recovered in the oyster ponds were separated by overnight sedimentation overnight-in a culture chamber at $16-{ }^{\circ} \mathrm{C}$. Samplesthe samples were then frozen at $-20{ }^{\circ} \mathrm{C} .0 .5 \mathrm{~g}$ of sedimentssediment was used for DNA extraction-_purposes.

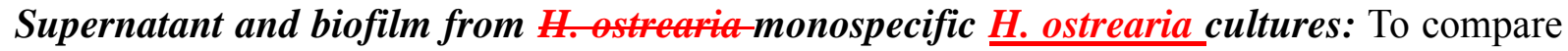
the structure of the bacterial community structure in the algal biofilm, i.e., which entails comparing the bacteria entrappedembedded in exopolysaccharides makingforming biofilm and epiphytic bacteria of $H$. ostrearia , with that of the suspended cells in the culture medium, the biofilm and the supernatant from the culture of $H$. ostrearia were separated. From cultures induring the exponential growth stage in 250 -_mL__Erlenmeyer flasks filled with $150 \mathrm{~mL}$ of ES 1/3 medium, $100 \mathrm{~mL}$ of the liquid -- attached at the bottom of the Erlenmeyer flasks -were carefully collected earefully-to avoid-any contact with the biofilm, and the few free alga (possibly associated with bacteria) were removed by centrifugation (SIGMA 3K30 Fisher Bioblock Scientific: $900 \mathrm{~g}, 90 \mathrm{~s}, 16-{ }^{\circ} \mathrm{C}$ ) to recoverensure recovering in the supernatant enlyjust the bacteria in suspension inwithin the culture medium. The supernatant was filtrated through a $0.22--\mu \mathrm{m}$ filter (cellulose nitrate membrane, Sartorius) so as to concentrate the bacteria on the filter, which was then frozen at $-20-^{\circ} \mathrm{C}$. Before DNA extraction, each filter was cut into small pieces of about $4 \mathrm{~mm}^{2}$. 
From thethis same culture, the remaining $50 \mathrm{~mL}$ were eliminated, and $30 \mathrm{~mL}$ of fresh ES $1 / 3$ medium were added into the Erlenmeyer flask-and; the algal biofilm was recovered by the meanmeans of the mechaniemechanical action of a sterile bar magnet. Microalgae and bacteria (epiphytic and those embedded in the biofilm), 2 were both recovered by centrifugation (SIGMA 3K30 Fisher Bioblock Scientific: $\left.6000 \mathrm{~g}, 5 \mathrm{~min}, 16{ }^{\circ} \mathrm{C}\right)$ ), and the samples were frozen at $-20-^{\circ} \mathrm{C}$ prior to DNA extraction.

Cultures of $\mathrm{H}$. ostrearia at differentvarious growth stages and generations: forFor both experiments, aboutapprox. $1.5-\cdot 10^{6}$ algal cells were collected afteronce the culture being homogeneizated, had been homogenized and then centrifuged (Universal 320 Hettich: $6000 \mathrm{~g}$, 10 min, $16^{\circ} \mathrm{C}$ ), and); the pellets containing suspended cells and cells of the biofilm were frozen at $-20-^{\circ} \mathrm{C}$ prior to DNA extraction.

The structures of the-bacterial community structures of the HO-BM and HO-R isolates were studied at the time-_scale of ane culture cycle. Samples were collected at the time of the transfer oftransferring $H$. ostrearia ininto the fresh ES 1/3 medium after being isolated and cultured in the laboratory duringfor one year (dayDay 0) and again after another 3, 7, 15 and 30 days.

The structures of the bacterial community structures of the HO-BM, HO-R, HO1-B, HO2-B, HO1-T and HO2-T isolates were also studied at the time-_scale of differentvarious subculturings of $H$. ostrearia: $\mathrm{T} 0, \mathrm{~T}+3, \mathrm{~T}+6$ and $\mathrm{T}+9$ months afterfollowing $H$. ostrearia isolation. At each timeof these times, a biometric measuremeasurement (cell length) was performedconducted on 90-200 algal cells withusing an Olympus AX70 PROVIS microscope and was determined using te; final determination relied on the LUCIA G software.

Axenic and non-axenic $H$. ostrearia cultures for metabolomic profiling: $\mathrm{HO}-\mathrm{BM}$ and $\mathrm{HO}-\mathrm{R}$ were cultivated in 250-_mL__Erlenmeyer flasks. Cells makingThe cells forming a biofilm at the bottom of the vessel were recovered induring the exponential growth stage, after being 
resuspended usingre-suspended with a sterile bar magnet, and homogenized and counted using a Nageotte chamber. Microalgae were then inoculated at $3-\cdot 10^{3}$ cells $\mathrm{mL}^{-1}$ (two replicates) in 100-_mL-_Erlenmeyer flasks containing fresh ES 1/3 medium and an antibiotic antimycotic solution (10,000 units penicillin, $10 \mathrm{mg}$ of streptomycin and $25 \mu \mathrm{g}$ of amphotericin $\mathrm{B} \mathrm{mL} \mathrm{m}^{-1}$, BioReagent, A5955 SIGMA) diluted at 1:50 or 1:100. The cultures were incubated in a culture chamber at $16^{\circ}{ }^{\circ} \mathrm{C}$ under $120 \mu \mathrm{mol}$ photons $\mathrm{m}^{-2} \mathrm{~s}^{-1}$ and a $14:-10 \mathrm{~h} \underline{10}$

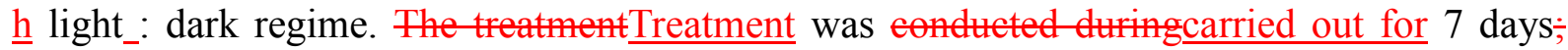
then, subsequent to which the culture supernatant was removed, ${ }_{\text {, and }}$ the algal biofilm was washed once with fresh ES $1 / 3$ medium to eliminate the antibiotics. The cells were resuspendedre-suspended with a sterile bar magnet in $25-30 \mathrm{~mL}$ of fresh ES $1 / 3$ medium $_{2}$ and $5 \mathrm{~mL}$ were transferred ininto 250 --mL-_Erlenmeyer flasks filled with $150 \mathrm{~mL}$ of fresh ES $1 / 3$ medium (triplicate). After 7-_days_of culture without antibiotic treatment, a second 7-day treatment was conducted with the same antibiotic antimycotic solution diluted to 1:50, followed by 7 days of culture without treatment. After the second treatment, the bacterial concentration was drastically reduced compared to the non-axenic cultures. These cultures were thus called "“"axenic" $"$. . Cells were collected induring the exponential growth stage: 200 $\mu \mathrm{L}$ of the supernatant of $\mathrm{HO}$ cultures were collected, filtered on $0.20--\mu \mathrm{m}$ PTFE membrane filters (Interchim) and frozen at $-80-^{\circ} \mathrm{C}$ prior to fingerprint acquisition. For non-axenic $H$. ostrearia cultures, from the stock cultures of HO-BM and HO-R induring the exponential growth stage in 250__mL___Erlenmeyer flasks, microalgae were inoculated in triplicatestriplicate in 24 wells platewell plates at $3-_{-}^{-} 10^{3}$ cells $\mathrm{mL}^{-1}$ to monitor the-daily algal growth by measuring the fluorescence of the-chlorophyll (BMG LabTech-: 440; $680 \mathrm{~nm}$ ). Microalga were incubated inunder the same conditions as for the axenic H. ostrearia cultures. After 6 days of culture (during the exponential growth stage), $200 \mu \mathrm{L}$ of the culture 
supernatant $\theta$ f culture-were collected, filtered on 0.20-_ $\mu \mathrm{m}$ PTFE membrane filters (Interchim) and frozen at $-80{ }^{\circ} \mathrm{C}$ prior to fingerprint acquisition.

\subsubsection{BacteriaBacterial DNA extractions}

DNA from i) -raw sediments, ii) as well as from supernatant derived from $H$. ostrearia monospecific $\underline{H}$. ostrearia cultures and iii) $H$. ostrearia cultures at different growth stages and generations $_{2}$ was extracted using a NucleoSpin ${ }^{\mathrm{TM}}$ soil kit (Macherey-Nagel, GmbH \& $\mathrm{Co}_{\overline{y_{2}}}$ Germany). In the specific case of the supernatant of $H$. ostrearia cultures at different growth stages and generations, firstthe initial steps of sample grinding were realizedperformed with an MM400 Bead Beater (Retsch Germany) $(3 \times 30 \mathrm{sec}, 25 \mathrm{~Hz})$. For biofilms, DNA was

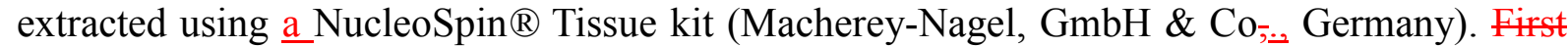

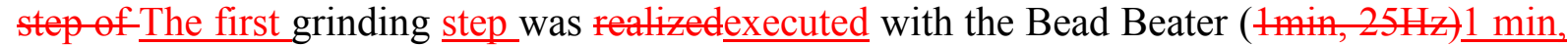
$25 \mathrm{~Hz})$, then a pre-lysing step of pre-lyzing includingthat included grinding $\left(56^{\circ}{ }^{\circ} \mathrm{C}, 105 \mathrm{~min}\right.$; grinding, $10 \mathrm{sec}, 25 \mathrm{~Hz}$ eachevery $30 \mathrm{~min}$ ) iswas applied according to the manufacturer'srecommendations.manufacturer's recommendations; DNA concentrations were also measured (SPECTROstar Nano, BMG LABTECH LVi Plate, Germany).

\subsubsection{PCR amplification}

The V3 region of the 16S rRNA gene was amplified using the 357F-GC and 518R primers [31]. The PCR reaction mixture contained $0.6 \mathrm{ng} . \mu \mathrm{L}^{-1}$ of DNA template, $0.1 \mu \mathrm{mol} . \mathrm{L}^{-1}$ of each primer, $200 \mu \mathrm{mol} . \mathrm{L}^{-1}$ of dNTP, 0.012 unit. $\mu \mathrm{L}^{-1}$ of Taq polymerase $1 \times$ reaction buffer, 2.5 mmol. $\mathrm{L}^{-1}$ of $\mathrm{MgCl}_{2}$, and $500 \mathrm{ng} \cdot \mu \mathrm{L}^{-1}$ of bovinbovine serum albumin and $5 \%(\mathrm{v} / \mathrm{v})$ of

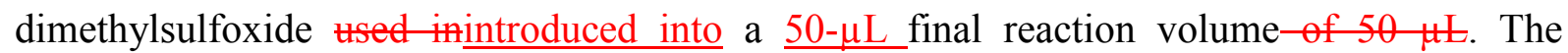
following cycling conditions were used for bacteriabacterial amplification: 1 cycle at $95-{ }^{\circ} \mathrm{C}$ for $8 \mathrm{~min}$, followed by 7 cycles of $95-{ }^{\circ} \mathrm{C}$ for $30 \mathrm{~s}, 68-^{\circ} \mathrm{C}\left(-1-^{\circ} \mathrm{C} /\right.$ cycle $)$ for $30 \mathrm{~s}, 72-^{\circ} \mathrm{C}$ for 50 
s, and 28 cycles at $95-{ }^{\circ} \mathrm{C}$ for $30 \mathrm{~s}, 62-{ }^{\circ} \mathrm{C}$ for $30 \mathrm{~s}, 72-{ }^{\circ} \mathrm{C}$ for $50 \mathrm{~s}$, and a final extension cycle at 72- ${ }^{\circ} \mathrm{C}$ for 30 min (CFX96 Touch $^{\mathrm{TM}}$, Thermal Cycler, Bio-Rad, US).U.S.).

\subsubsection{Temporal temperature gradient electrophoresis (TTGE) and fingerprint} acquisition

PCR products (from Section 2.3.3) were separated according toby their GC\% using a Temporal Temperature Gel Electrophoresis [32]. TTGE analyses were performed using a DCode ${ }^{\mathrm{TM}}$ SystemDCode ${ }^{\mathrm{TM}}$ System (Bio-Rad, US).U.S.). The 9.5\% polyacrylamide gel was composed of two parts: a top, urea-free “_ "concentration"”-" part (stacking gel) en aboutapplied approx. $1 \mathrm{~cm}$ from the base of the wells upward $\bar{\xi}_{2}$ and a bottom, "_denaturation"- part (resolving gel), at $8 \mathrm{~mol} . \mathrm{L}^{-1}$ urea. Fifteen microliters of PCR products were deposited ininto each well. Migration was performedtook place in $1.25 \times$ TAE for $750 \mathrm{~min}$ at $50 \mathrm{~V}$, with a temperature gradient from $65{ }^{\circ} \mathrm{C}_{-}^{\circ}$ to $70-^{\circ} \mathrm{C}$, i.e $-{ }_{-,}, 0.4-^{\circ} \mathrm{C}$ per hour. The gels were stained using GelRed ${ }^{\mathrm{TM}}$ (Biotium, US) $\underline{\text { U.S.) }}$ ) and then imaged under UV light (Molecular Imager ${ }^{\circledR G e l}$ Doc $^{\mathrm{TM}}$ XRSystem, Bio-Rad, US andU.S., along with Image Lab ${ }^{\mathrm{TM}}$ software).

\subsection{UntargetUntargeted metabolomic profiling}

UHPLC-ESI-QToF-using, through implementing a non-targeted analysisanalytical strategy byvia high--_resolution mass spectrometry (HRMS) [33ł], was used to detect small soluble extracellular target compounds produced by the bacteria and $H$. ostrearia recovered from the culture medium.

LC-TOF/MS analysis samples: Aliquotsaliquots $(5 \mu \mathrm{L})$ of each sample from the supernantantsupernatant of $H$. ostrearia cultures (see sectionsection 2.3.1.) were separated on a Kinetex ${ }_{2} 1.7--\mu \mathrm{m} \mathrm{C} 18100 \AA$ (Phenomenex) column $(150 \times 2.1 \mathrm{~mm})$ maintained at $40-^{\circ} \mathrm{C}$, using an Agilent 1290 Infinity LC system with a gradient mobile phase $\left(0.5 \mathrm{~mL} \mathrm{~min}{ }^{-1}\right)$ 
comprising $0.1 \%$ aqueous acetic acid (A) and acetonitrile containing $0.1 \%$ acetic acid (B).

289 The gradient present was as follows: $5 \% \mathrm{~B}$ from 0 to $2.4 \mathrm{~min}$, raiseincreasing to $25 \% \mathrm{~B}$ from 2.4 to $4.5 \mathrm{~min}$, then raiseraised to $30-\% \mathrm{~B}$ from 4.5 to $11 \mathrm{~min}$, finally raise toreaching $100-\%$

B from 11 to $14 \mathrm{~min}$ and maintainheld there until $16.5 \mathrm{~min}$, subsequentlyfollowed by a decrease to 5\% B until 20 min have elapsed and maintainthen maintained at 5\% B until 25 min. The eluent was directly introduced into the mass spectrometer by an electrospray. Mass spectrometry was performedconducted on a 6540 UHD Q-TOF mass spectrometer (Agilent Technologies, Waldbronn, Germany), operating in positive ion mode. The capillary voltage, fragmentor voltage and skimmer were set teat 3,900, 150 and $60 \mathrm{~V}$, respectively. The sheath gas was measured at $3500^{\circ} \mathrm{C}\left(12 \mathrm{~mL} \mathrm{~min}^{-1}\right)$ and the drying gas at $175-^{\circ} \mathrm{C}\left(5 \mathrm{~mL} \mathrm{~min}^{-1}\right)$ andwith a 43-psi nebulizer-43 psi. Nitrogen was used as the collision gas. Mass spectra were acquired in a full scan analysis over an $\mathrm{m} / \mathrm{z}$ range of $50-\_1,700$ using an extended dynamic range and storage ina centroid mode. Data of storage. The data station operating software was the MassHunter Workstation Software (versionBversion B.06). sectionSection 2.2.) ), and their bacterial structures were compared (for raw sediments,

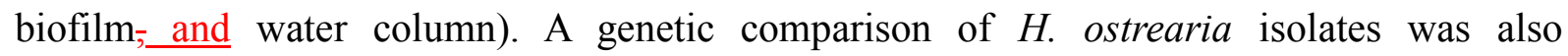
performed. For the monitoring ofcarried out. To monitor the temporal dynamic of the structure of the-bacterial community en-structure over the course of anone algal culture cycle, experiments were replicated two times and also for the monitoring of the temporal dynamic of 
temporal dynamics during a 9-monthsmonth serial subculturing campaign. For the nontargeted metabolomic investigation, analyses were carried out in triplicate.

Data exploitationprocessing: The 16S rRNA banding patterns on imaged TTGE gels were analysed withanalyzed using the Molecular Analyst Fingerprinting software: FPQuestTM

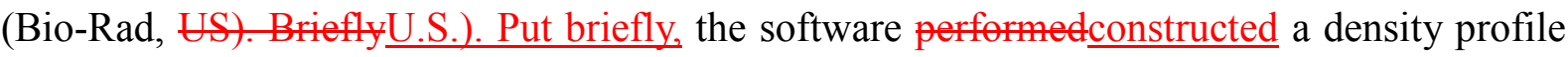
through each lane and calculated the relative contribution of each band to the total band signal in a lane, after applying a rolling disc to serve as background subtraction. The banding patterns of the samples in each lane were compared with each otherone another. The Unweighted Pair Group Method with Arithmetic Mean (UPGMA) was used to draw a dendrogram from similarity coefficients. To towerdecrease the bias, we ehoseopted to analyze band patterns by usingexercising the densitometric-curve option, as alreadypreviously used by Kuntz and colleagueset al. [34] and Seghers and colleagueset al. [35],] instead of the banddetection option. For the metabolomic investigation, data were processed using the MassHunter Qualitative Analysis software (Agilent Technologies) where), with compounds werebeing extracted from the raw data usingwith the Molecular Feature Extraction (MFE) algorithm, and. Moreover, a principal component analysis were performed-was conducted using the Mass Profiler Professional B12.05 statistical package (also from Agilent Technologies).

\section{Results}

\subsection{Bacterial community structure of sediment samples from oyster ponds}

The structure of the bacterial community from oyster-ponds-pond bulk sediment samples 
$15 \%$ of similarity with other localities. On the contrary In contrast, samples from the other localities haddisplayed a similar bacterial community structure $(>$ (i.e. $>85 \%)(\underline{\%}$, see Fig. 2$)$.

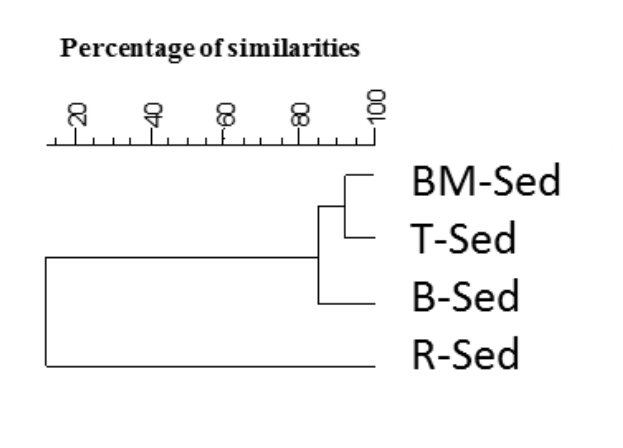

Fig. 2-: Bacterial community structure of sediment samples (Sed) collected in oyster ponds from differentvarious localities (B: Bouin, BM: La Barre-de-Monts, R: Isle of Réisland, T: La Tremblade).)

3.2. - Community structure of bacteria recovered from the biofilm after Haslea ostrearia isolation and from bacteria suspended bacteria fromin the water column

FirstlyFirst of all, the structure of the bacterial community from the sediment compared to that of the biofilm after $H$. ostrearia isolation differed stronglyconsiderably (only $10 \%$ of similarity between sediment and biofilm) ${ }_{2}$ data not shown). This result demonstrates that the bacteria associated towith $H$. ostrearia were specific to the microalga. biofilm with those of the water column (WL), i.e.,., suspended bacterial cells (Fig. 3) showed), revealed similarities that did not exceed $10 \%$. 


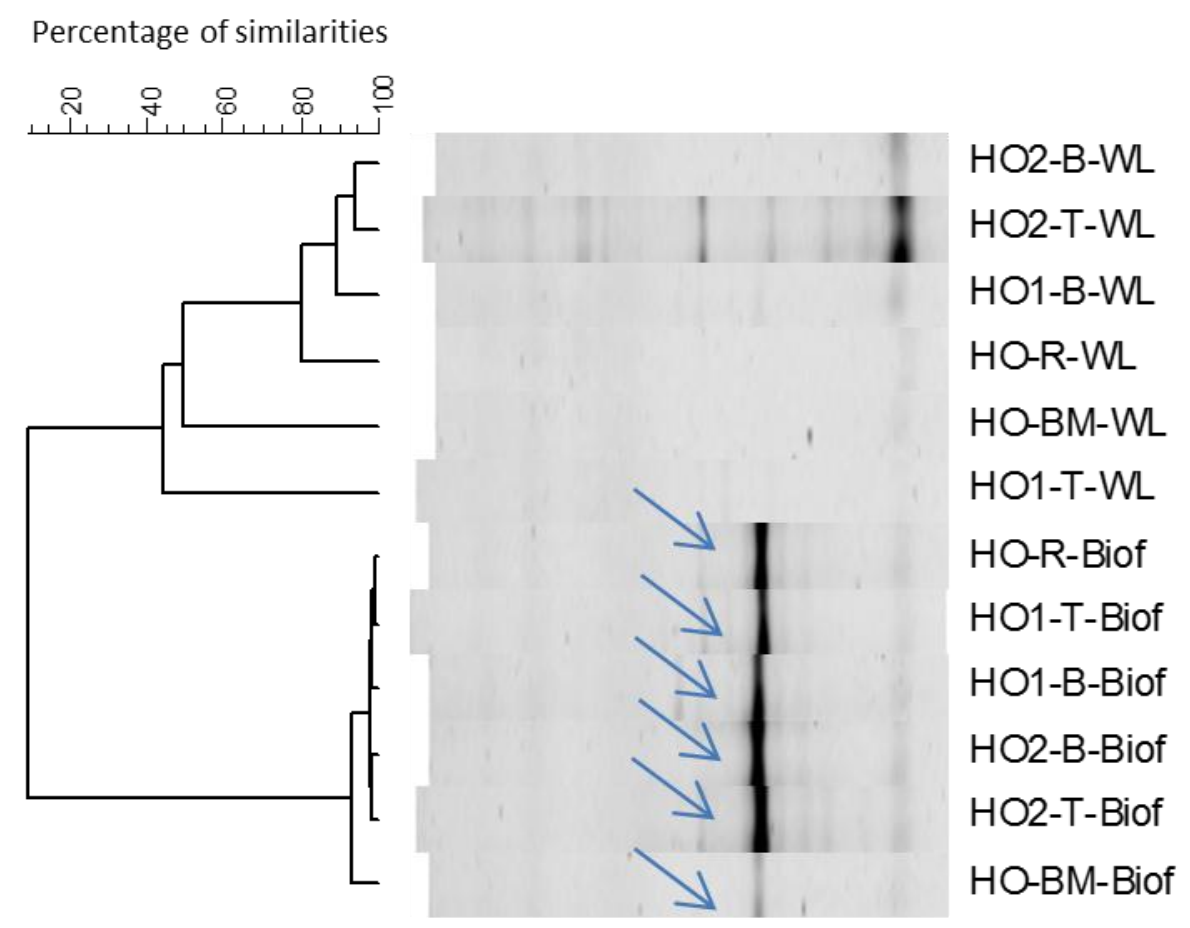

Fig. 3-: TTGE analysis of the bacterial community structure from biofilm (Biof) and water column (WL) samples after isolation of $H$. ostrearia from differentvarious localities and subculturing in ES 1/3 medium inunder laboratory conditions (B: Bouin, BM: La Barre-de-Monts, R: Isle of Ré-island, T: La Tremblade). Arrows indicate the position of the band corresponding to the suspected chloroplastic and/or mitochondrial DNA of H. ostrearia.

RegardingWith respect to the biofilm, the observed similarities in bacterial community structures were greater thanexceeded $90 \%$ regardless of the geographic origin of the $H$. ostrearia isolates. The presence of a band with-high-_intensity (band (see arrows in Fig. 3) was supposedassumed to berepresent chloroplastic and/or mitochondrial DNA from $H$. ostrearia. The resulting phylogenetic tree with and without this band wasremained unchanged.

For the water column, similarities beenamong the differentvarious algal isolates were more variable and lower overall lower-(e.g., extending to $95 \%$ between $\mathrm{HO} 2-\mathrm{B}$ and $\mathrm{HO} 2-\mathrm{T})$. 


\section{3. -Metabolic fingerprinting differentiation of Haslea ostrearia isolates from La} Barre de Monts and Isle of Ré istand

Two distinct $H$. ostrearia isolates were used for the metabolomic analysis, namely: HO-BM

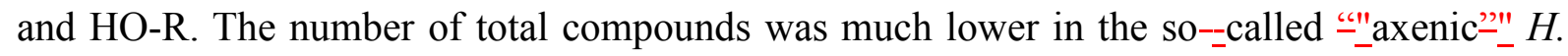
ostrearia cultures-accounting, which account for algal compounds (Fig. 4A) $\underline{4 a}$ ), compared to

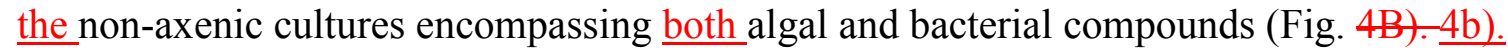
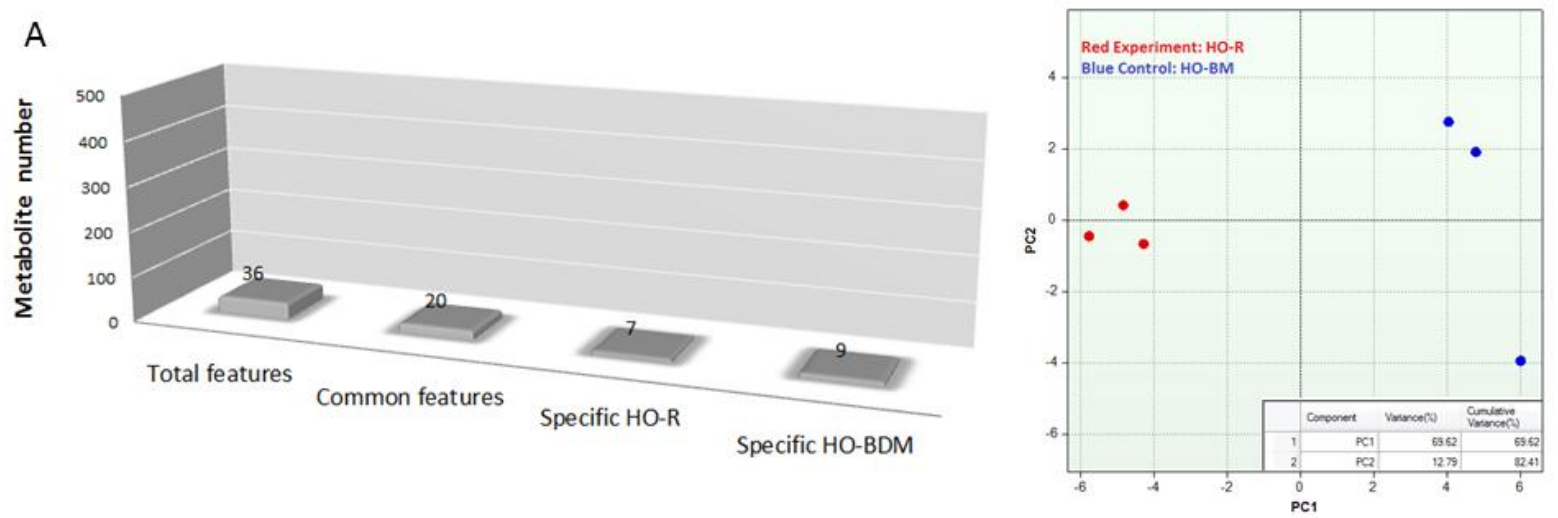

B
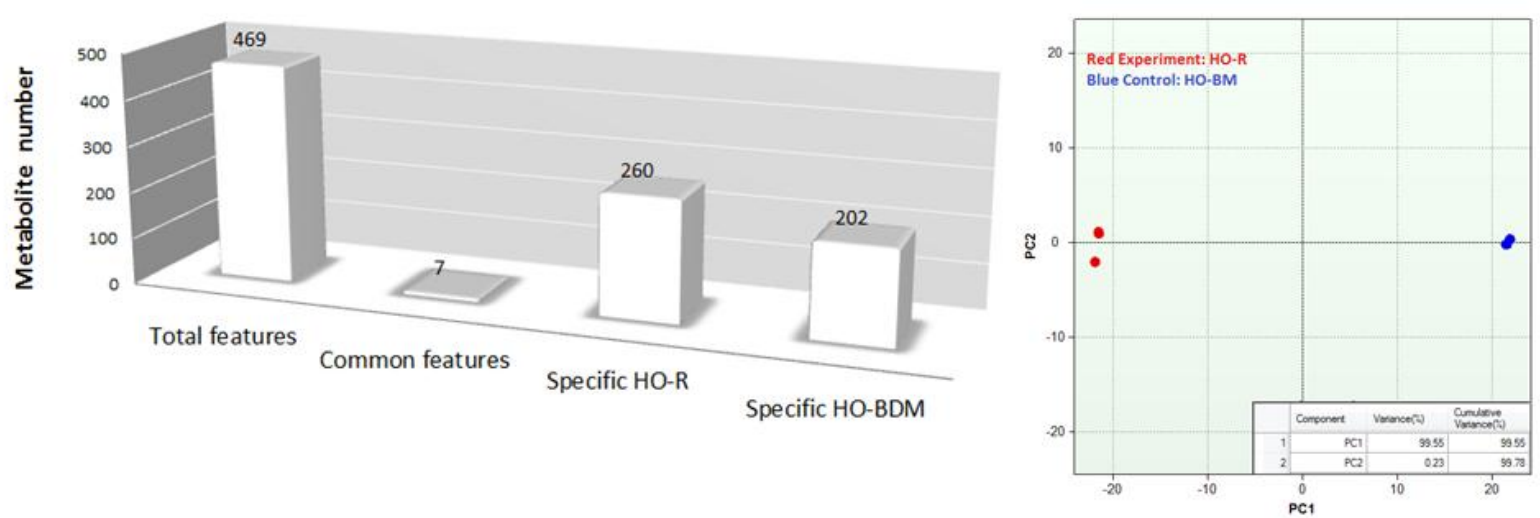

Fig. 4:: Number of compounds recovered from HO-BM and HO-R isolate cultures (left) and the related principal component analysis representations (right) (in considering $\mathrm{p}<0.05$ and fold-change $>$

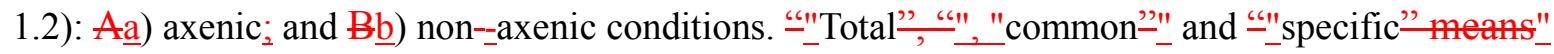
refers to the total compounds recovered, compounds shared by both isolates and compounds specific to each isolatesisolate, respectively. Analyses All analyses were performed in triplicate. 
388 Axenic conditions showed-were associated with a high number of common compounds (20 out of 36) and a few numberssmall number of compounds were-specific to each isolate (7 and 9 for $\mathrm{HO}-\mathrm{R}$ and $\mathrm{HO}-\mathrm{BM}_{2}$ respectively).

ItThe opposite was shown the contraryexposed with non-axenic conditions, i.e, number of common compounds (7 out of 469) and), while 260 and 202 compounds were specific to $\mathrm{HO}-\mathrm{R}$ and $\mathrm{HO}-\mathrm{BM}_{2}$ respectively.

Here In this instance, a Principal Component Analysis (PCA) approach efto pattern recognition was used to distinguish betweenthe classes. The data ofData from the control group (blue) and the experimentexperimental group (red) were processed; and a data matrix was gained. Figure 4 A, B showedgenerated. Figures $4 \mathrm{a}$ and b display the 2D PCA score plot of the control group and the experimentexperimental group inunder both axenic and nonaxenic conditions. PCA analyses have confirmed that the differences in the metabolic profiling between $\mathrm{HO}-\mathrm{R}$ and $\mathrm{HO}-\mathrm{BM}$ waswere more significant inunder non-axenic conditions than in-axenic conditions. The points of non-axenic model distribution points are indeed less dispersed (99\% of the variance explained by the axis 1 of the PCA (PC1) inunder non-axenic conditions against onlyvs. just $69 \%$ inunder axenic conditions).

3.4. -Structure of the bacterial community from Haslea ostrearia isolates aton two time-_scales

This experiment, performed in duplicate with two H. ostrearia isolates (HO-BM and HO-R) showed a), found perfect repeatability of the TTGE analysis (Fig. 5). At the seale of a culture cycle scale, a marked evolution efin the bacterial community wascould be observed. 

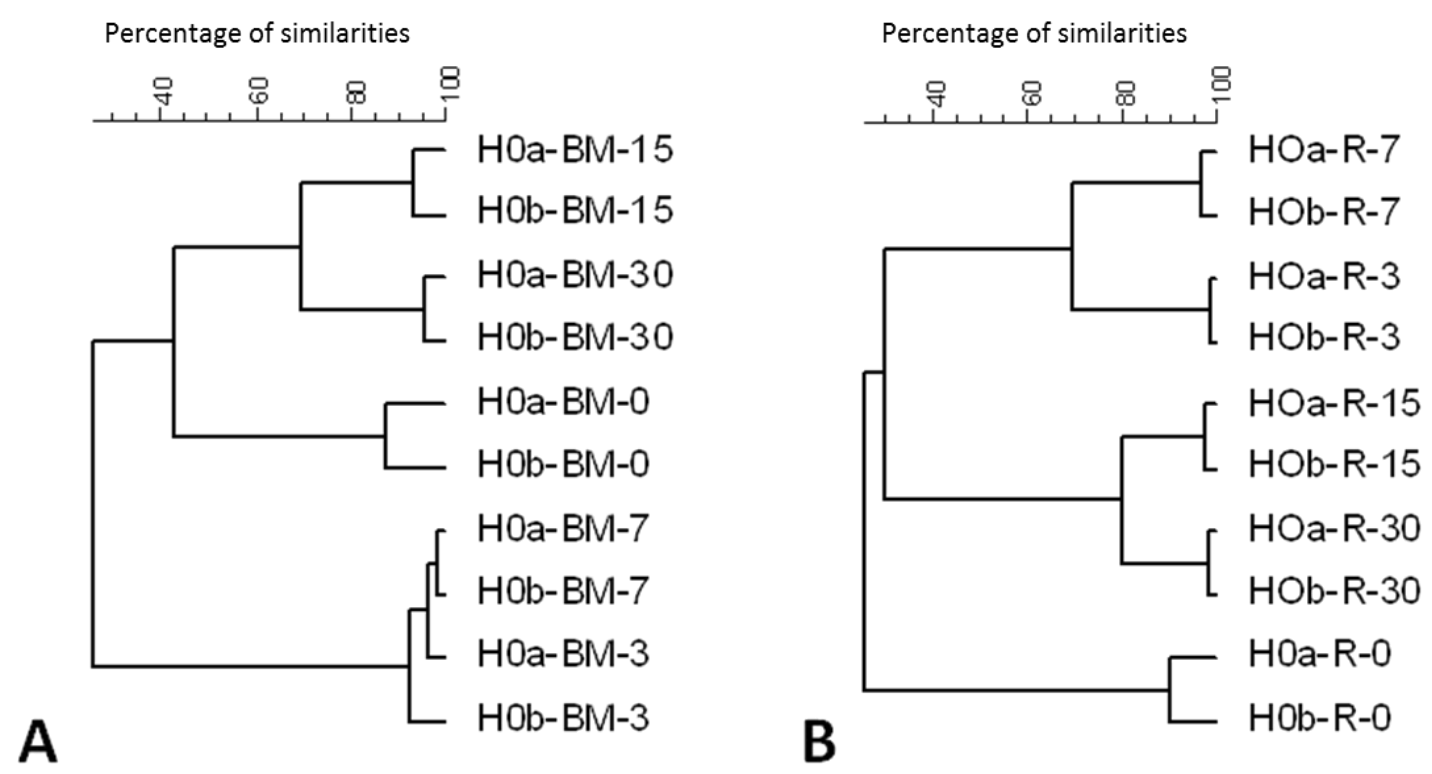

Fig. 5: Structure of the global bacterial community (suspension cells and biofilm cells) during a growth cycle of two Haslea ostrearia isolates (at daydays 0, 3, 7, 15 and 30).A): a) HO-BM: La Barre-de-Monts, Bb) HO-R: Isle of Ré-island).. Letters a and b arestand for the two experimental replicates-of the experiment.

Three differentdistinct clusters -emerged, all of which were related to the algal growth stage: day 0 (initial structure of the bacterial community structure), days 3 and 7 days-(exponential phase), and days 15 and 30 days-(stationary phase and decline phase).

\subsubsection{Over a 9-monthsmonth serial subculturing campaign}

Samples were recovered at the same growth stage, i.e.,. exponential-growth stage... A quiterather low similarity efin the bacterial structure was observed between $\mathrm{T} 0$ and the

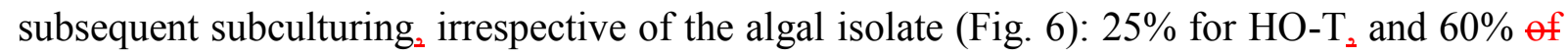
similarity for HO-BM, HO-B and HO-R. It showsThis result demonstrates that once $H$. ostrearia was isolated and cultivated inunder laboratory conditions, the bacterial community 


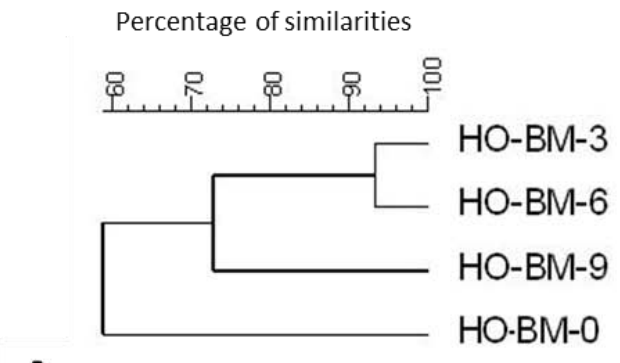

A

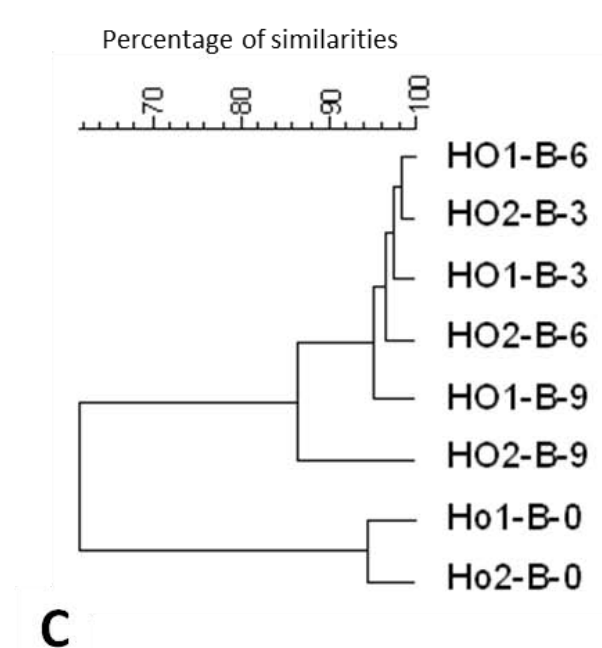

C HO-B.

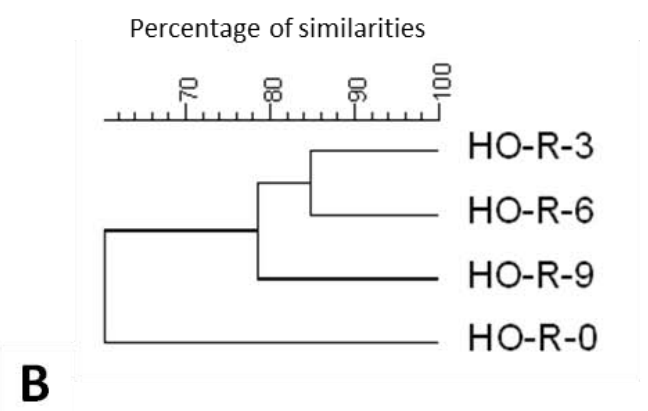

Percentage of similarities

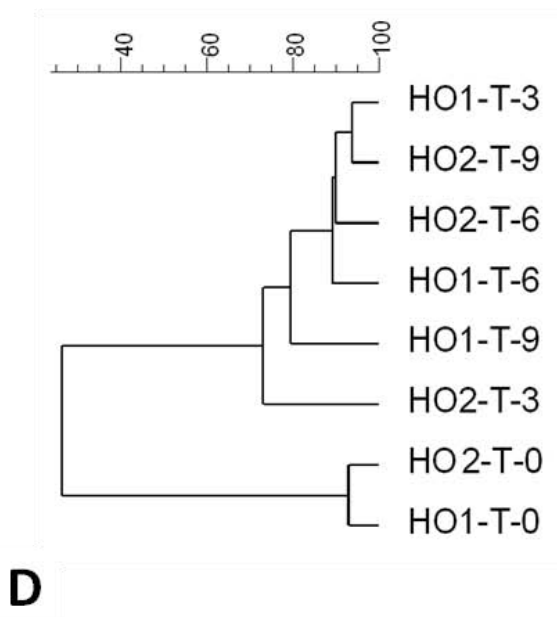

435

436

months, the bacterial community structure was fairly stable regardless of the-isolate origin. Similarities -in the bacterial community for each algal isolate during the 3- up-to 9-month period of culture were indeed greater thandid in fact top $70 \%$, with a maximum of $86 \%$ for 

subculturing, campaign (i.e-, about $28.6-\% \pm 2.6 \%(\%$, data not shown) hadexerted no influence on the bacterial community structure.

\section{Discussion}

\section{1. -Bacterial community structure of sediment samples from oyster ponds}

Except for the HO-R isolate-displaying only, which displayed just a $15 \%$ similarity with other

isolates, highstrong similarities of thein bacterial structurestructures were shownobserved between isolates $\left(>\_85 \%\right)(\%$, Fig. 2$\left.)\right)$, while the sampling locations are separated by up to at hundred kilometres apart 100 kilometers (Fig. 1) but with similar), although their climatic conditions are similar. For HO-R, the tow similarityrelative dissimilarity is most likely due to the depth of the-sampling depth, which was higher as-compared to the sampling conditions for other localities-: not only was the sediment that deposited on the bottom of oyster pond wasponds collected ${ }_{2}$ but alseso was some underlying sediment makingconstituting the bed of the oyster pond (specific physic-chemicalphysicochemical characteristics). We thenhave thus postulated that the bacterial assemblage of the sediment deposited on the bottom enof the eyster pondponds and the underlying enesediment were distinct.

462 For other localities showing high levels of similarities, the specific

463 eharacteristiecharacteristics and functioning of the oyster ponds could explain these results. These ecosystems are indeed ecosystems-managed by humanshuman beings for an-optimal oyster production. Nutrients (quality, amount) for oysters-but als $\mathrm{\theta}_{2}$ as well as for all living being of the oyster pondspond organisms including algae and bacteria ${ }_{2}$ were most 
eolleagueset al. [18] for oyster ponds efin the same areas as those studied in the present study. herein.

Whether or not the oysters were present at the time of sampling or not _ no oysters were

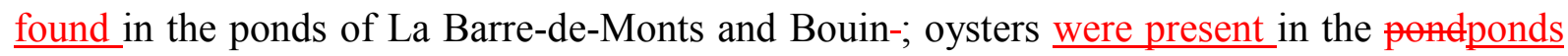
of La Tremblade and Isle of Ré-Istand-) did not seem to influence on the structure of -the bacterial community. The structure. Since the pond management history beingis an unknown, it eanmay be assumed that empty ponds were filled with oysters shortly before the samplingssampling campaign and moreover that the composition of the seawater composition in these ponds remained unchanged in the meantime.-

\section{2. -Community structure of bacteria recovered from the biofilm and suspended} bacteria from the water column after Haslea ostrearia isolation

Once $H$. ostrearia washad been isolated from the sedimentssediment samples of the differentvarious localities, it iswas reasonable to assume that the specific biotope of each locality no longer hadexerted an effect. Indeed, H. ostrearia isolates were further cultivated inunder the same controlled conditions (i.e. culture medium, light, temperature).

Compared to the structure of the-bacterial community structure in the bulk sediment, the structure relatedrelative to the phycosphere of $H$. ostrearia, i.e, $\overline{-}_{-}$epiphytic bacteria and those entrappedembedded in the biofilm, was very distinct with cross-sample similarities between samples that did-not exceedexceeding 10\% (data not shown). This result is usuallytypically observed in higher plants whenwhere the bacteria of the rhizosphere are compared to those of the bulk soil [36]. Regarding the TTGE pattern band numbers-of TTGE patterns, it was surprising to note that they were higher for the biofilm samples than for the bulk sediment samples. On the contrary, Schäfer and colleagueset al. [24] observed on the contrary that the bacterial biodiversity of the phycosphere was towlimited when compared to the complexity of 

bacterial assemblages in bulk seawater. Nonetheless-different, various results were shown when bacteria of the rhizosphere bacteria were compared to those of bulk soil bacteria [36]. In our case ${ }_{2}$ it can be supposedassumed that the extracellular compounds of $H$. ostrearia are sufficiently diversified to support the growth of various bacterial populations. At least 36 (up toout of 469) compounds were indeed detected (Fig. 4) depending on whether H. ostrearia was axenic or not.

Irrespective of the geographic origin of the $H$. ostrearia samples, the bacterial structure of the biofilm samples was found to be similar (Fig. 3), including the HO-R isolate, while the bacterial structure of the sediment samples for this locality strongly differed markedly (Fig. 2). This result shows that the bacterial structure of the phycosphere is specific to H. ostreariaIt was; it has indeed been demonstrated that the structure of the bacterial community linked teassociated with the microalgal strain was specific to the microalgae [20, 24, 27]. For HO-R, weit could then be concluded that the particular bacterial structure of the sample recovered from the sediment was due solely to the characteristic ofinfluenced by the biotope characteristics, i.e, , $_{-}$the specific eharacteristics of the sediment- characteristics.

The significant differences in the structures of the-bacterial community structures between the bacteria of the phycosphere bacteria and those from the bulk water column bacteria $(15 \%$ similarity between the two groups, Fig. 3) eonfirmsconfirm the majorsignificant effect of $H$ ostrearia in the establishment ofestablishing a specific community hosted by the phycosphere. The highest level of bacterial structures similaritiesstructure similarity observed between biofilm samples (>-90\%)\%), as compared to $40 \%$ up to- $90 \%$ for the suspended bacteria of the same samples-showed, has also revealed the predominant partrole of $H$. ostrearia in the establishment ofestablishing a bacterial structure specific to this species. Indeed theThe nutrient composition of $H$. ostrearia biofilms was-most probably , in all likelihood, very different tefrom that of seawater ${ }_{2}$ as the result of biofilm enrichment by algal exudates. The 
specificity of the bacterial community, with respect to the algae in the environment where bacteria live, ${ }_{2}$ was already shownpreviously presented by Eigemann and colleagueset al. [37f], who demonstrated that the influence of the algal host overruleddominated the effect of changes in environmental conditions. Liu and colleagueset al. [38] demonstratedshowed that the phytoplankton community succession influencedinfluences changes in bacterial community composition. In the specific case of toxin production ef toxins such as(like domoic acid) by algae, it has been shown by-Sison-Mangus and colleagueset al. [39] reported that the three tested species of Pseudo-nitzschia_species, which vary in toxin production, had phylogenetically distinct bacterial communities; and, moreover, that toxic Pseudo-nitzschia had lowerexhibited less microbial diversity than non-toxic Pseudo-nitzschia. Bruckner and colleagueset al. [40] indicatedsuggested an adaptation of Proteobacteria and Bacteroidetes tein the microenvironment created by the diatom biofilm. For the suspended bacteria in the water column, the variousvarying geographic origins of the samplings, mostsamples, which very probably showingreveal differences, $\bar{y}_{-}$even $_{\text {slight }} \overline{\bar{y}}_{-}$in biotope characteristics, most likely explainedexplains the differences in the-bacterial structures asgiven that they were not under the direct influence of $H$. ostrearia.

Regarding the two isolates of La Tremblade (HO1-T and HO2-T), the lowlimited similarity of the suspended bacterial eellscell structures (40\%, Fig. 3) eouldmight be the result of initially different bacterial structures whichthat did not converge after $H$. ostrearia isolation-contrary to, in contrast with what was observed for the biofilm (>_95\%) as the result ofdue to the considerable influence of exudation.

\section{3. -Metabolic profiles of HO-R and HO-BM}

One of the highestgreatest differences in the structure of the bacterial community structure was shown for HO-BM and HO-R isolates forin both the biofilm and the-water column (Fig. 
3) and can); this finding may be explained by the differences in the metabolic profiles (Fig. 4) - Indeed). The axenic cultures of $H$. ostrearia displayedindeed display distinguishable metabolomes (Fig. 4A), although not very different $4 \mathrm{a}$ ), though their differences remain minimal: 20 compounds in common out of 36-2 which is not surprising since the biometric analysis of the isolates by scanning electron microscopy (SEM), based on the density of transapical and longitudinal striations of the frustule-showed, indicates that they belong to the H. ostrearia species.

-To access the bacterial metabolom, it couldmight have been tempting to subtract the number of compounds of the axenic treatment (Fig. $4 \AA \underline{4 a}$ ) from the number of the xenic compounds (Fig. 4B). But one should4b). Extreme care must be tery carefulexercised however since some bacteria-microalgae interactions cannot be excluded. Bacteria and microalgae indeed do not have probably sameexhibit different metabolic profiles depending on whether $H$. ostrearia is cultivated as a monoculture or in association with the bacteria of the phycosphere. Yet it bacteria. It should still be noted that the metabolic profile of the bacteria- $H$. ostrearia association is very specific efto HO-R and $\mathrm{HO}-\mathrm{BM}_{2}$ with enlyjust 7 common compounds out of 469 .

It cannot be excludedoverlooked that a few compounds were not those produced by the alga and/or the bacteria ${ }_{2}$ but thoseinstead compounds of other organisms since the culture medium (ES 1/3) consists of filtered (to $0.2 \mu \mathrm{m}$ ) seawater enriched with minerals. We have assumed that themedium sterilization of the medium-degraded almostnearly all of the remaining compounds. The seawater used for the preparation ofto prepare the culture medium was the same for the cultivation of cultivating the two isolates, thenthus avoiding any bias resulting effrom possible geographicalgeographic differences. 
4.4. -Structures of the bacterial community from Haslea ostrearia isolates aton two time-_scales

At the scale of a-culture cycle (eascale (i.e. one up-to two weeks), the changes in the structure of the-bacterial community structure (Fig. 5) were related to the different-various growth stages of the growth of $H$. ostrearia, i.e, $\overline{\bar{y}}_{-}$lag time, exponential growth stage $\overline{\bar{j}}_{\overline{1}}$ and stationary stage, most probablylikely as a result of exudates in various amountsvarying quantities and compositions. This phenomenon is well documented for bacteria growing in the rhizosphere of plants [41]. At the seasonal time-_scale-of the season, Liu and colleagueset al. [38] demonstrated that phytoplankton community succession influenced the composition efinfluences the bacterial community- composition.

The change in the structure of the bacterial community structure is eycliecyclical. When $H$. ostrearia was sampled at the same (exponential) growth stage (exponential stage) duringover a nine-month period (e.a.,i.e. 30 subculturing), the structure ofsubculturings), the bacterial community structure remained ratherquite stable $(75 \%$ up-to $85 \%$ similarity between 3 and 9 months) (, see Fig. 6). It can be assumed that the wholeentire bacterial community associated towith $H$. ostrearia (entrappedembedded, epiphytic and free bacteria) was transmitted at each subculturing. The decrease in the frustule size of diatoms, already shownwitnessed for $H$. ostrearia [42], did not impactalter the bacterial structure althougheven though the algal size of some isolates at the end of the experiment (between 52 and $82 \mu \mathrm{m}_{2}$ with an average atof $61_{\overline{9}, 2}$ $\mu \mathrm{m})$ was in the range for auxosporulation (i.e. between 50 and $68 \mu \mathrm{m} \underline{68 \mu \mathrm{m}}[43,44]$ ).

Between the first subculturing (T-0) and the third month, the bacterial structure changed significantly (25\% up-to $60 \%$ of-similarity) as the result of the adaptation of the-bacterial community adapting to the maintenance culture conditions with a-stabilization after 3 months due to the well-controlled conditions for the culture of the $H$. ostrearia isolates. This finding suggests that the laboratory conditions effor $H$. ostrearia (culture medium composition, 
temperature, light) also influence the composition of the bacterial assemblage, as

593 demonstrated by Sapp and colleagueset al. [45]. These]; these authors showedfound a shift in 594 the bacterial populations associated with diatoms between isolation and cultivation of algal 595 cells, with an increase in the number of phylotypes belonging to members of Gammaproteobacteria members.

\section{Conclusion}

599

600

For the first time, this study has analyzed the bacterial ecosystem surrounding the marine

601

602

603

604

605

606

607

608

609

610

611

612

613

\section{References}

diatom $H$. ostrearia and showed that thethis bacterial structure is specific to the geographic origin of the microalgal isolate. In $\underline{\mathrm{Under}}$ laboratory conditions, afteronce $H$. ostrearia isolationhas been isolated from oyster ponds, the structure of the-bacterial community structure was shown to be resilient over a 9-month subculturing although the structure of the bacterial communitydespite structural changes at the culture time scale of a culture depending enaccording to the growth stage. LikewiseSimilarly, the differences in the bacterial structures of two $H$. ostrearia isolates (HO-R and $\mathrm{HO}-\mathrm{BM}$ ) resulted ingave rise to specific metabolomicsmetabolomic profiles. These profiles were more distinct with non-axenic microalgae, i.e-, including . with inclusion of their associatingassociated bacteria, than with axenic enes,microalgae, thus suggesting reciprocal relationships between bacteria and $H$. ostrearia cells. 
615 [1] R. Gastineau, N. Davidovich, G. Hansen, J. Rines, A. Wulff, I. Kaczmarska, G. Carrier, 616 Halea ostrearia-like Diatoms: Biodiversity out of the Blue. In Advances in Botanical Re617 search: sea plant (2014) pp. 441-465.

618 [2] R. Simonsen, The diatom plankton of the Indian Ocean expedition of RV" Meteor" 1964619 1965. Gebrüder Borntraeger (1974).

620 [3] Ranson G, L'absorption de matières organiques dissoutes par la surface extérieure du corps chez les animaux aquatiques, Ann. Inst. Oceanogr. 4 (1927) 49-174.

622 [4] J.P. Bergé, N. Bourgougnon, S. Alban, F. Pojer, S. Billaudel, J.C. Chermann, G. Franz,

623

624

625 Antiviral and anticoagulant activities of a water-soluble fraction of the marine diatom Haslea ostrearia, Planta medica 65 (1999) 604-609.

[5] R. Gastineau, J.B. Pouvreau, C. Hellio, M. Morançais, J. Fleurence, P. Gaudin, N. Bourgougnon, J.L. Mouget, Biological activities of purified marennine, the blue pigment produced by the diatom Haslea ostrearia and responsible for the greening of oysters, J. Agric. Food Chem. 60 (2012b) 3599-3605.

[6] J. B.Pouvreau, M. Morançais, F. Taran, P. Rosa, L. Dufossé, F. Guérard, S. Pin, J. Fleurence, P. Pondaven, Antioxidant and free radical scavenging properties of marennine, a blue-green polyphenolic pigment from the diatom Haslea ostrearia (Gaillon/Bory) Simonsen responsible for the natural greening of cultured oysters, J. Agric. Food Chem. 56 (2008) 62786286.

[7] T. Lebeau, P. Gaudin, G.A. Junter, L. Mignot, J.M. Robert, Continuous marennin production by agar-entrapped Haslea ostrearia using a tubular photobioreactor with internal illumination, Appl. microbiol. biotechnol. 54 (2000) 634-640.

[8] T. Lebeau, P. Gaudin, R. Moan, J.M. Robert, A new photobioreactor for continuous marennin production with a marine diatom: influence of the light intensity and the immobilisedcell matrix (alginate beads or agar layer), Appl. Microbiol. Biotechnol. 59 (2002) 153-159. 
640 [9] N. Rossignol, T. Lebeau, P. Jaouen, J. M. Robert, Comparison of a two membrane photo641 bioreactors, with free or immobilized cells, for the production of pigments by a marine dia642 tom, Bioproc. Eng. 23 (2000a) 495-501.

643 [10] N. Rossignol, P. Jaouen, J.M. Robert, F. Quéméneur, Production of exocellular pigment 644 by the marine diatom Haslea ostrearia Simonsen in a photobioreactor equipped with im645 mersed ultrafiltration membranes, Bioresour. Technol. 73 (2000b) 197-200.

646 [11] J. M. Robert, Fertilité des eaux des claires ostréicoles et verdissement: utilisation de 647 l'azote pas les diatomées dominantes. PhD thesis, University of Nantes, (1983) $281 \mathrm{pp}$.

648 [12] C. Sauvageau, A propos de la présence de la diatomée bleue dans la Méditerranée. 649 Travaux des laboratoires (Arcachon), 6 (1906) 46-59.

650 [13] L. Barillé, J. Haure, E. Pales-Espinosa, M. Morançais, Finding new diatoms for intensive 651 rearing of the pacific oyster (Crassostrea gigas): energy budget as a selective tool, 652 Aquaculture 217 (2003) 501-514.

653

[14] B. Cognie, Alimentation de l'huître Crassostrea gigas (Thumberg): étude des méca-

654

655

656

657

658

659

660

661

662

663

nismes de sélection des particules et des processus rétroactifs entre le bivalve et les microalgues. PhD Thesis, University of Nantes (France), (2001) 166 pp.

[15] F. Piveteau, Etude des arômes de l'huître creuse Crassostrea gigas : conséquences d'un affinage à l'aide des microalgues Skeletonema costatum et Haslea ostrearia. PhD Thesis, University of Nantes (France), (1999) 213 pp.

[16] J.L. Mouget, G. Tremblin, A. Morant-Manceau, M. Morançais, J.M. Robert, Long-term photoacclimation of Haslea ostrearia (Bacillariophyta): effect of irradiance on growth rates, pigment content and photosynthesis, Eur. J. Phycol. 34 (1999) 109-115.

[17] G. Tremblin, R. Cannuel, J.L. Mouget, M. Rech, J.M. Robert, Change in light quality due to a blue-green pigment, marennine, released in oyster-ponds: effect on growth and photosyn- 
664

665

666

667

668

669

670

671

672

673

674

675

676

677

678

679

680

681

682

683

684

685

686

687

thesis in two diatoms, Haslea ostrearia and Skeletonema costatum, J. Appl. Phycol. 12 (2000) $557-566$.

[18] V. Turpin, Etude des événements physico-chimiques et biologiques présidant à la prolifération d'Haslea ostrearia (Simonsen) dans les claires ostréicoles de la région de MarennesOléron: implications dans la maîtrise du verdissement. PhD Thesis, University of Nantes (France), (1999) 208 pp.

[19] R.Gastineau, N.A. Davidovich, J.F. Bardeau, O.I. Davidovich, Y. Rincé, P. Gaudin, E.J. Cox, J.L. Mouget, Haslea karadagensis sp. nov. (Bacillariophyta), a new diatom from the Black Sea producing a novel blue pigment, Eur. J. Phycol. 47 (2012a) 469-479.

[20] S. A. Amin, M.S. Parker, E.V. Armbrust, Interactions between diatoms and bacteria, Microbiol. Mol. Biol. Rev. 76 (2012) 667-684.

[21] J.N. Rooney-Varga, M.W. Giewat, M.C. Savin, S. Sood, M. LeGresley J.L. Martin, Links between phytoplankton and bacterial community dynamics in a coastal marine environment, Microb. Ecol. 49 (2005) 163-175.

[22] W. Bell, R. Mitchell, Chemotactic and growth responses of marine bacteria to algal extracellular products, Biol. Bull. 143 (1972) 265-277.

[23] M. Sapp, A.S. Schwaderer, K.H. Wiltshire, H.G. Hoppe, G. Gerdts, A. Wichels, Speciesspecific bacterial communities in the phycosphere of microalgae? Microb. Ecol. 53 (2007a) 683-699.

[24] H. Schäfer, B. Abbas, H. Witte, G. Muyzer, Genetic diversity of 'satellite' bacteria present in cultures of marine diatoms, FEMS Microbiol. Ecol. 42 (2002) 25-35.

[25] M.L. Guannel, M.C. Horner-Devine, G. Rocap, Bacterial community composition differs with species and toxigenicity of the diatom Pseudo-nitzschia, Aquat. Microb. Ecol. 64 (2011) 117-133. 
691

692

693

694

695

696

697

698

699

700

701

702

703

704

705

706

707

708

709

710

[26] D. Schwenk, L. Nohynek, H. Rischer, Algae-bacteria association inferred by 16S rDNA similarity in established microalgae cultures, Microbiology Open 3 (2014) 356-368.

[27] A. M. Lakaniemi, C.J. Hulatt, K.D. Wakeman, D.N. Thomas, J.A. Puhakka, Eukaryotic and prokaryotic microbial communities during microalgal biomass production, Bioresour. technol. 124 (2012) 387-393.

[28] R. Ramanan, Z. Kang, B.H. Kim, D.H. Cho, L. Jin, H.M. Oh, H.S. Kim, Phycosphere bacterial diversity in green algae reveals an apparent similarity across habitats, Algal Res. 8 (2015) 140-144.

[29] L. Provasoli, Media and prospects for the cultivation of marine algae. In Cultures and Collections of Algae. Proceedings of the US-Japan Conference, Hakone, September 1966, (1968) pp. 63-75.

[30] T. Lebeau, G.A. Junter, T. Jouenne, J.M. Robert, Marennine production by agarentrapped Haslea ostrearia Simonsen, Bioresour. Technol. 67 (1999) 13-17.

[31] E. Jaffrès, D. Sohier, F. Leroi, M.F. Pilet, H. Prévost, J.J. Joffraud, X. Dousset, Study of the bacterial ecosystem in tropical cooked and peeled shrimps using a polyphasic approach, Int J Food Microbiol 131 (2009) 20-29.

[32] G. Muyzer, K. Smalla, Application of denaturing gradient gel electrophoresis (DGGE) and temperature gradient gel electrophoresis(TGGE) in microbial ecology, Antonie van Leeuwenhoek 73 (1998) 127-141.

[33] F. Mondeguer, J.P. Antignac, Y. Guitton, F. Monteau, S. Le Borgne, P. Hess, Nouvelle stratégie de caractérisation non ciblée de type métabolomique au service de l'identification de composés bioactifs accumulés dans les mollusques bivalves, Spectra Analyse (2012) 24-33. 
[34] J. Kuntz, N. Nassr-Amellal, M. Lollier, J. E. Schmidt, T. Lebeau, Effect of sludges on bacteria in agricultural soil. Analysis at laboratory and outdoor lysimeter scale. Ecotoxicology and Environmental Safety, 69(2) (2008) 277-288.

[35] D. Seghers, S.D. Siciliano, E.M. Top, W. Verstraete, Combined effect of fertilizer and herbicide applications on the abundance, community structure and performance of the soil methanotrophic community. Soil Biol. Biochem., 37 (2005), 187-193.

[36] A.D. Kent, E.W. Triplett, Microbial communities and their interactions in soil and rhizosphere ecosystems, Annu. Rev. Microbiol. 56 (2002) 211-236.

[37] F. Eigemann, S. Hilt, I. Salka, H.P. Grossart, Bacterial community composition associated with freshwater algae: species specificity vs. dependency on environmental conditions and source community, FEMS Microbial. Ecol. 83 (2013) 650-663.

[38] L. Liu, J. Yang, H. Lv, Z. Yu, Synchronous dynamics and correlations between bacteria and phytoplankton in a subtropical drinking water reservoir, FEMS Microbiol. Ecol. 90 (2014) 126-138.

[39] M.P. Sison-Mangus, S. Jiang, K.N. Tran, R.M. Kudela, Host-specific adaptation governs the interaction of the marine diatom, Pseudo-nitzschia and their microbiota, ISME J. 8 (2014) 63-76.

[40] C.G. Bruckner, R. Bahulikar, M. Rahalkar, B. Schink, P.G. Kroth, Bacteria associated with benthic diatoms from Lake Constance: phylogeny and influences on diatom growth and secretion of extracellular polymeric substances. Appl. Environ. Microbiol. 74 (2008) 77407749.

[41] N.C. Uren, Types, amounts, and possible functions of compounds released into the rhizosphere by soil-grown plants. In: Pinton R, Varanini Z, Nannipieri P (eds) The rhizosphere: biochemistry and organic substances at the soil-plant interface. Marcel Dekker, New York (2000) pp. 19-40. 
736 [42] P. Gaudin, T. Lebeau, J.M. Robert, Microalgal cell immobilization applied to the long737 term storage of the diatom Haslea ostrearia, J Appl Phycol 18 (2006) 175-184.

738 [43] D. Neuville, P. Daste, Observations préliminaires concernant l'auxosporulation chez la 739 diatomée Navicula ostrearia (Gaillon) Bory en culture in vitro, C. r. hebd. séances Acad. sci., $740 \quad$ (1975) 1753-1756

741 [44] N. A. Davidovitch,J. L. Mouget, P. Gaudin, Heterothallism in the pennate diatom Haslea 742 ostrearia (Bacillariophyta), Eur. J. Phycol. 44(2) (2009) 251-261.

743 [45] M. Sapp, A. Wichels, G. Gerds, Impacts of cultivation of marine diatoms on the associat744 ed bacterial community, Appl Environ Microbiol. 73 (2007b) 3117-3120. 


\section{Acknowledgments}

This study was carried out under the COSELMAR project supported by IFREMER and Nantes University and co-funded by the Regional Council of the "Pays de la Loire". The authors thank la Roche-sur-Yon Agglomération for its participation to finance bead beater. We thank Thomas Glauner, Maxime Grives, John Lee and Thierry Faye of Agilent Technologies for their collaboration on the Agilent Q-ToF technology and software. We are also grateful to Romain Gastineau for COI1 and COI6 primers, Clovis Genuy and Thierry Jauffrais for sampling from La Barre-de-Monts and Ré island, and Astrid Lerouxel for the map with $H$. ostrearia localities. 


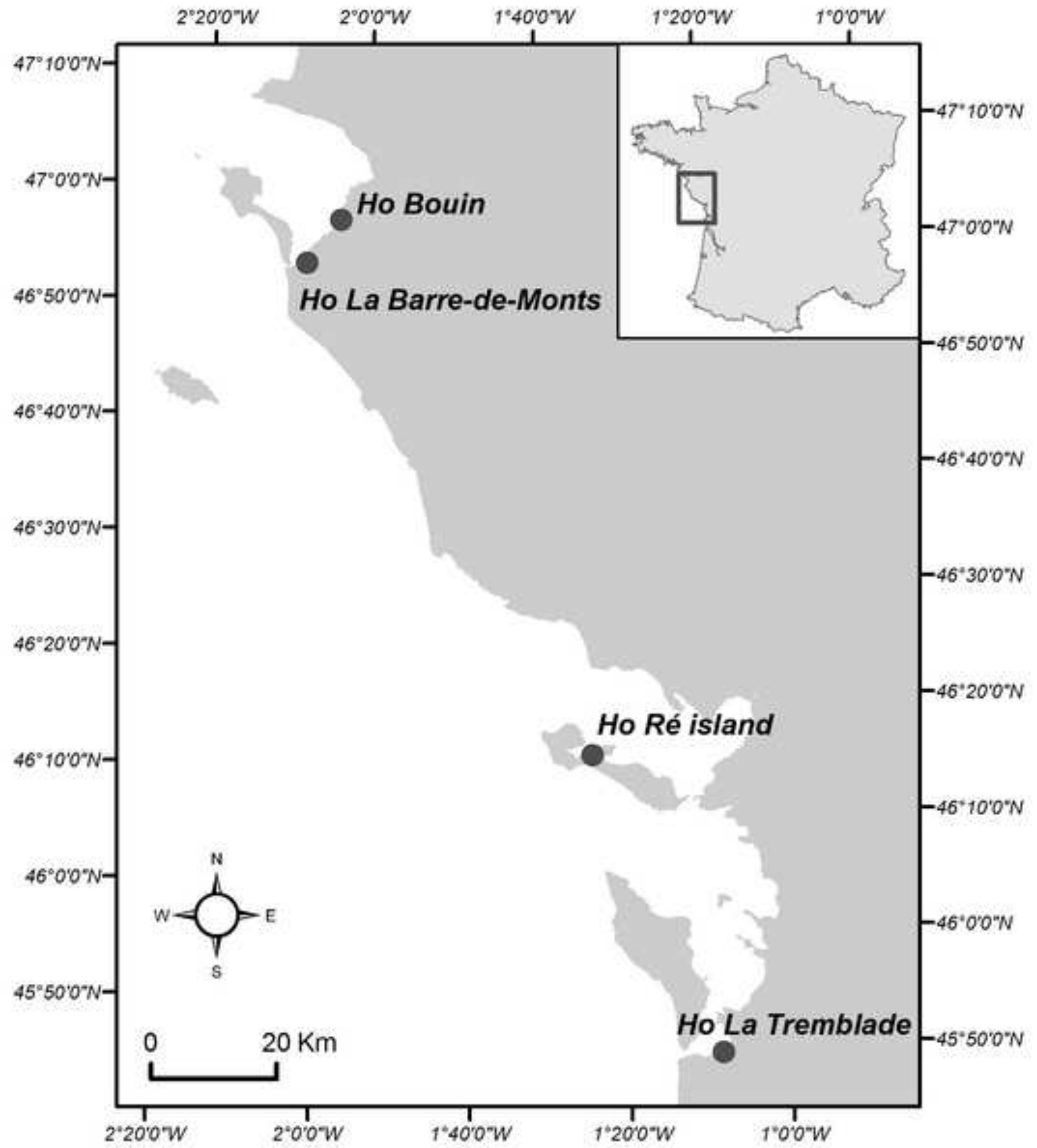


Click here to download high resolution image

\section{Percentage of similarities}
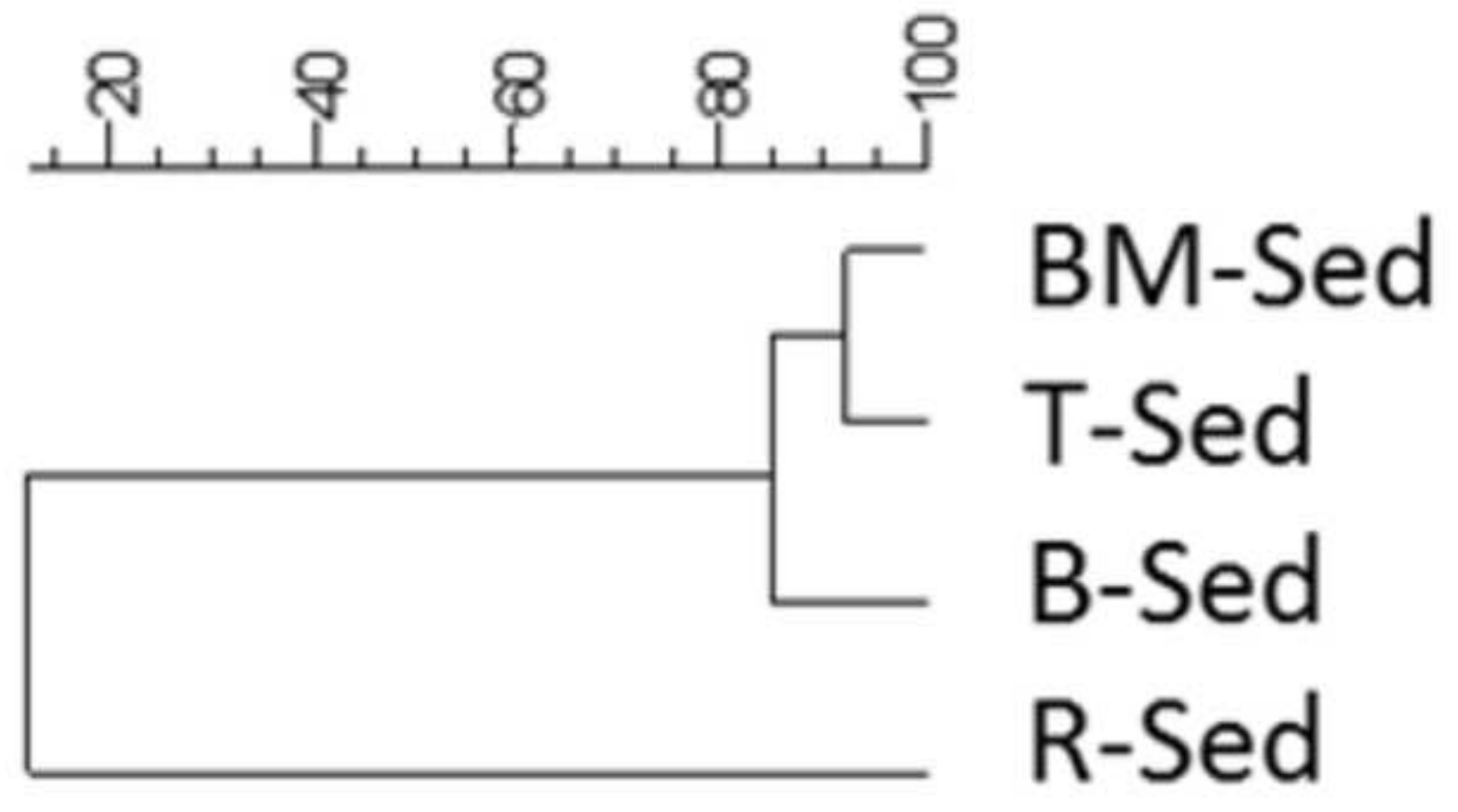

$$
\begin{aligned}
& \text { BM-Sed } \\
& \text { T-Sed } \\
& \text { B-Sed } \\
& \text { R-Sed }
\end{aligned}
$$




\section{Percentage of similarities}

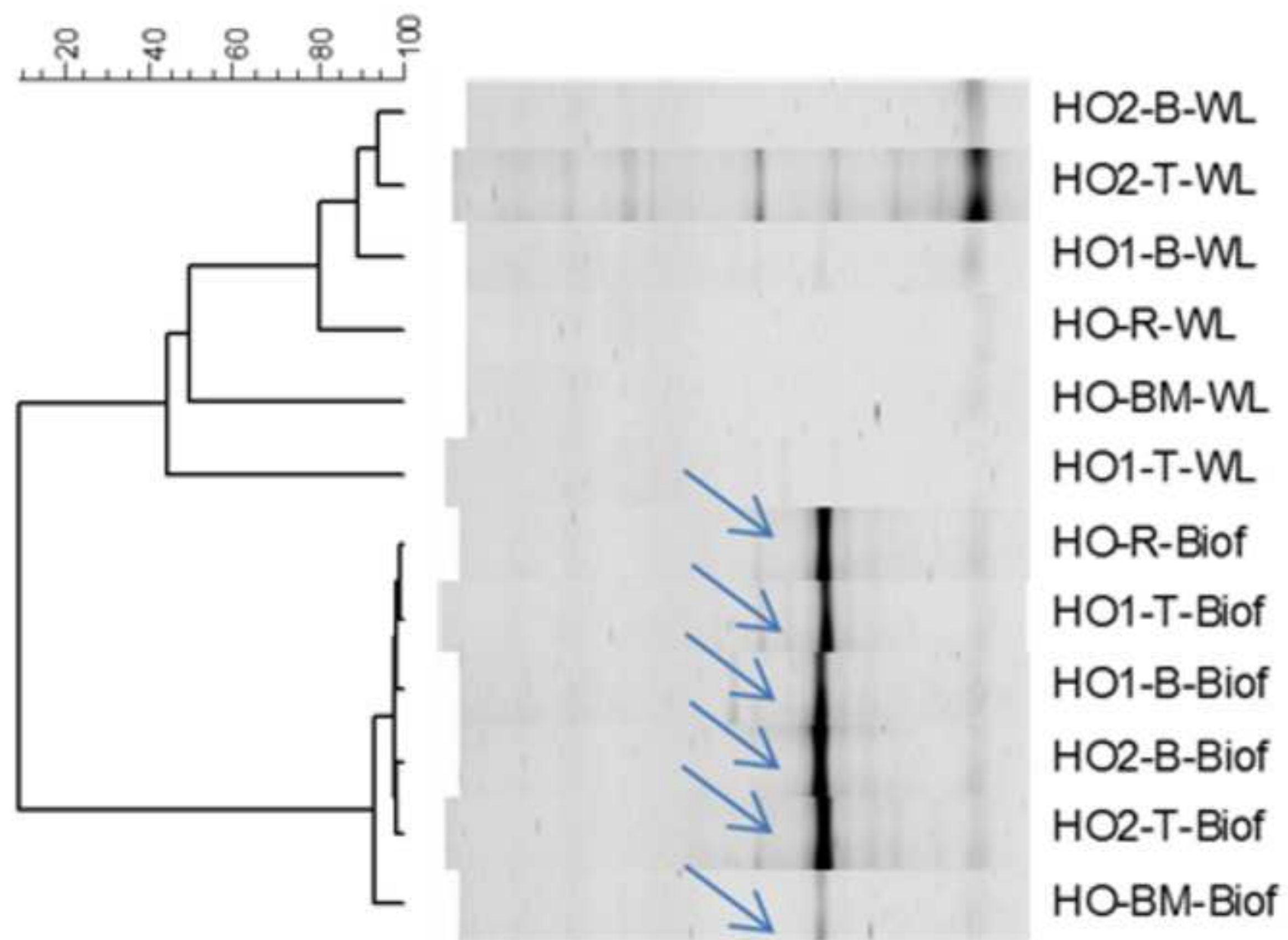



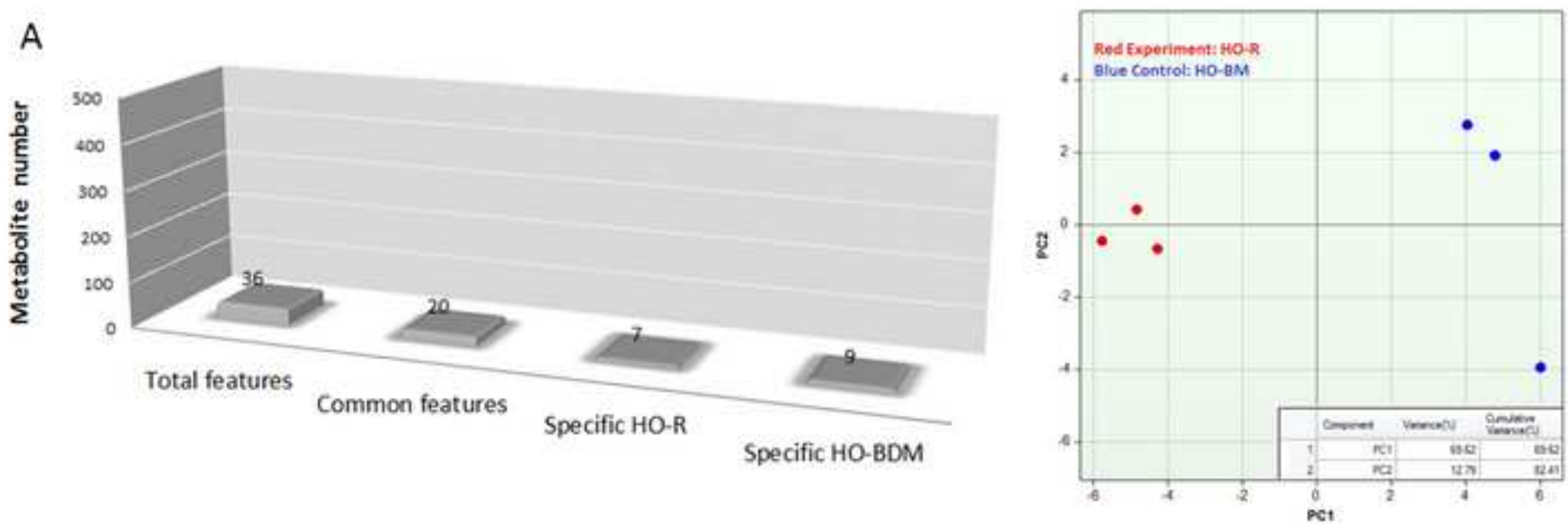

B
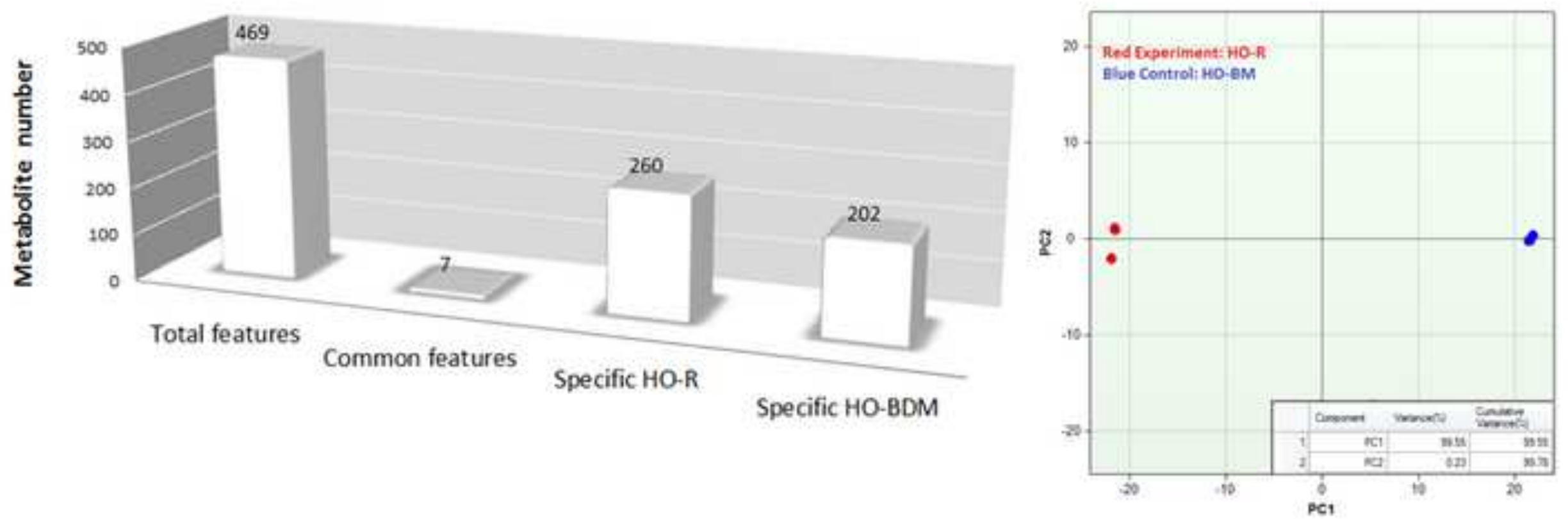

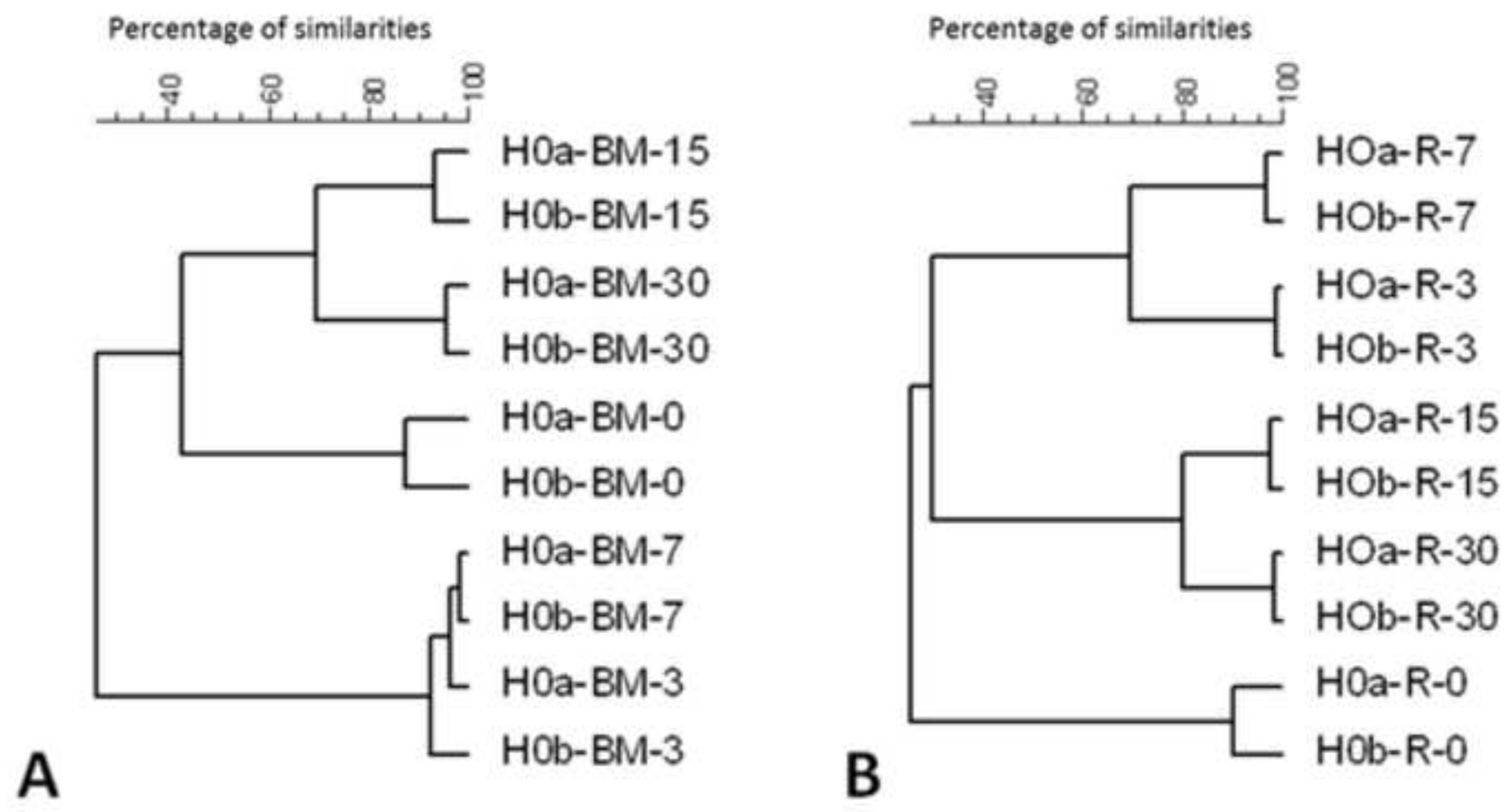
Percentage of similarities
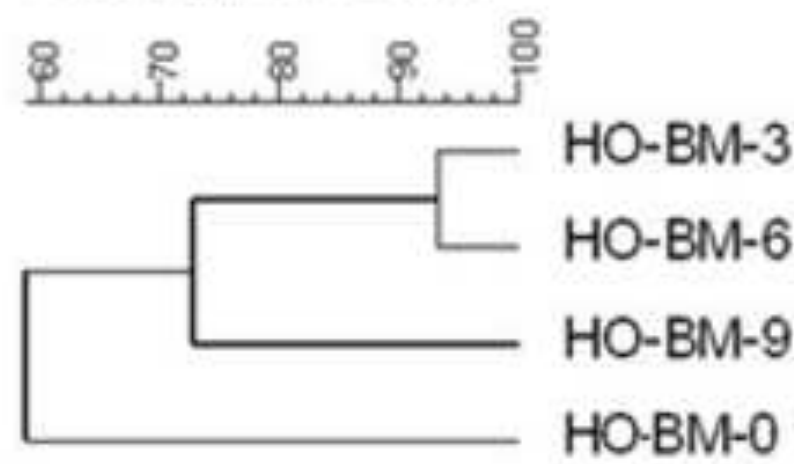

A

Percentage of similarities
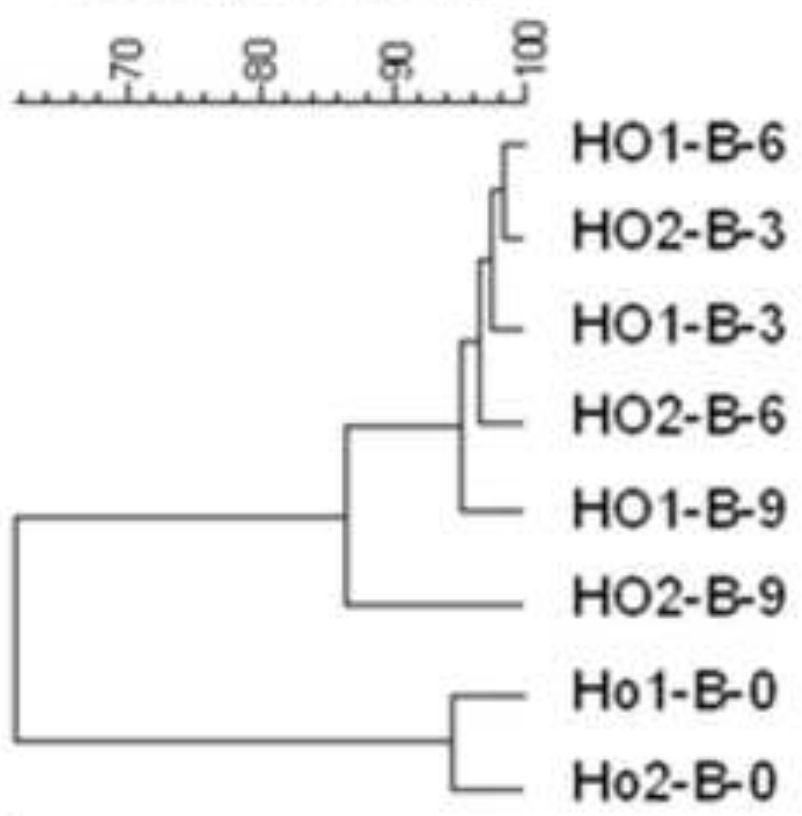

Percentage of similarities

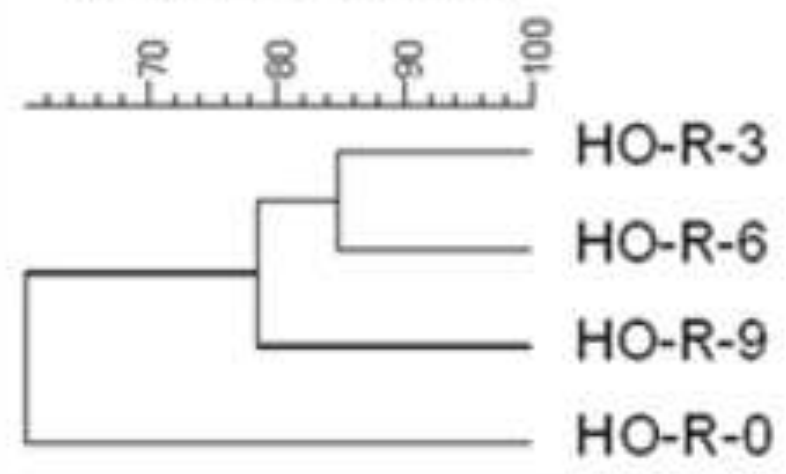

B

Percentage of similarities

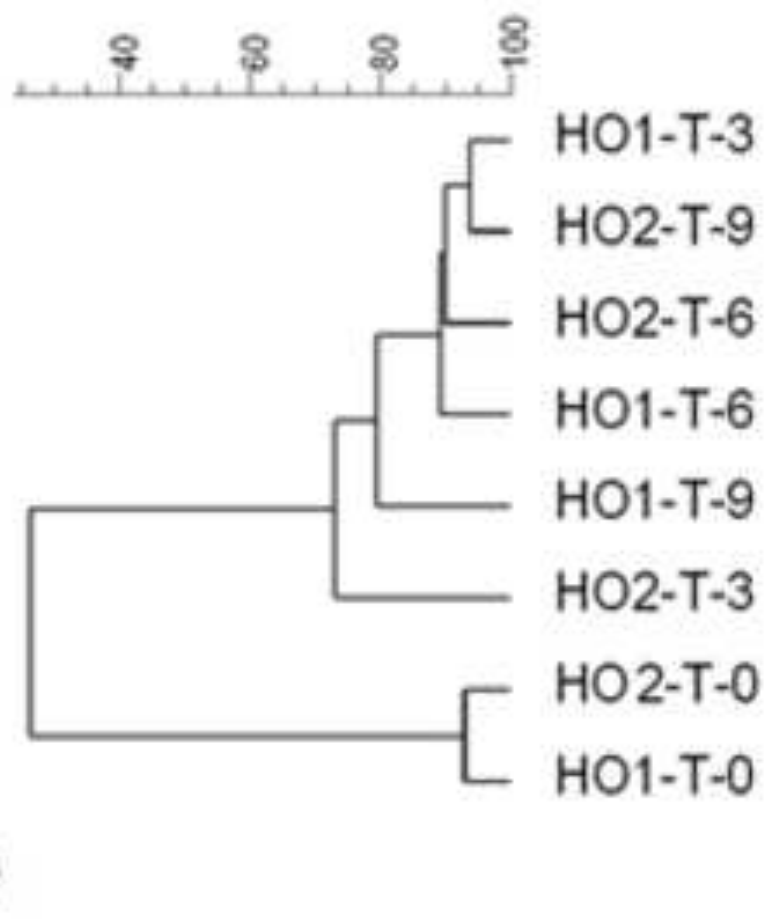

C 


\section{Highlights:}

The bacterial structures (TTGE) of H. ostrearia biofilm and bulk sediment are distinct.

A bacterial structure varies with the geographic origin of $H$. ostrearia.

Metabolic profiles are more distinct for bacteria-algae than for algal monocultures.

The bacterial structure of the phycosphere is specific to the algal growth stage.

The bacterial structure of the phycosphere remains unchanged over a 9-month subculturing. 


\section{Bacterial community structure of the marine diatom Haslea ostrearia}

2

$3 \quad$ Alexandra Lépinay ${ }^{1,2}$, Hervé Capiaux ${ }^{3}$, Vincent Turpin ${ }^{1}$, Florence Mondeguer ${ }^{4}$, Thierry

4 Lebeau $^{2} *$

5

6

7

\section{* Corresponding author}

Keywords: biofilm, ecology, metabolic fingerprinting, microalgae, phycosphere, TTGE.

\begin{abstract}
Haslea ostrearia produces a water-soluble, blue-green pigment, called marennine, with proven economic benefits (as a bioactive compound used to green oysters, which improves their market value). Incomplete knowledge of the ecological features of this marine diatom complicates its cultivation. More specifically, the ecology of bacteria surrounding H. ostrearia in ponds is what remains unknown. The structure of this bacterial community was previously analyzed by means of PCR-TTGE before and after isolating H. ostrearia cells recovered from
\end{abstract}


4 localities in order to distinguish the relative parts of the biotope and biocenose and to describe the temporal dynamics of the bacterial community structure at two time scales (2 weeks vs. 9 months). The bacterial structure of the phycosphere differed strongly from that of bulk sediment. The level of similarity between bacteria recovered from the biofilm and suspended bacteria did not exceed $10 \%$. On the other hand, similarities among the bacterial community structures in biofilms were above $90 \%$ regardless of the geographic origin of the algal isolates, while the percentages were lower for suspended bacteria. The differences in bacterial structures of two $H$. ostrearia isolates (HO-R and HO-BM) resulted in specific metabolomic profiles. The non-targeted metabolomic investigation revealed more distinct profiles in the case of this bacteria-alga association than for the $H$. ostrearia monoculture. At the culture cycle scale under laboratory conditions, the bacterial community depended on the growth stage. When $H$. ostrearia was subcultured for 9 months, a shift in the bacterial structure was observed as of 3 months, with the bacterial structure stabilizing afterwards ( $70 \%-86 \%$ similarities), in spite of the size reduction of the $H$. ostrearia frustule. Based on these results, an initial insight into the relationships between H. ostrearia and its surrounding bacteria could be drawn, leading to a better understanding of the ecological feature of this marine diatom.

\section{Haslea ostrearia is a cosmopolitan species of diatoms commonly found on the French} Atlantic coast, especially in oyster ponds of the Bay of Marennes-Oléron and Bay of Bourgneuf [1]. This diatom has long been the subject of curiosity [2] and became a topic of investigations due to its water-soluble, blue-green pigment, called marennine, which is responsible for the greening of oysters. This blue-green pigment, produced when H. ostrearia 
blooms, is released into the seawater, at which point the ponds turn green. At this stage, $H$. ostrearia is the dominant diatom species in ponds, and oyster farmers take advantage of this phenomenon by immersing their oysters in these shallow waters for 'refinement' (fattening) and greening, since these last two stages of raising oysters guarantee product quality and improve a farm's profits. Beyond its benefit in aquaculture for greening oysters [3], marennine has been shown to possess several biological functions with potential biotechnological applications, namely: i) antibacterial, anticoagulant and antiviral activities [4, 5]; ii) antioxidant activity [6]; and iii) antitumor and antiproliferative effects of the aqueous extract from $H$. ostrearia on solid tumors (lung and kidney carcinoma and melanoma cell line molecules). Until now however, an incomplete knowledge of the ecological conditions under which this microalgae develops in its natural ecosystem has complicated controlling the cultivation of $H$. ostrearia, even though dedicated photobioreactors adapted to the physiological specificity of this microalga - through the use of artificially immobilized cells were designed at the laboratory scale [7-10]. This microalga indeed exhibits several types of behavior, primarily benthic, occasionally planktonic but also epiphytic [11, 12], thus making immobilization a relevant course of action. The ecophysiology of $H$. ostrearia is complex and moreover not yet completely understood. In oyster ponds, $H$. ostrearia can outcompete other microalgae yet is also being consumed by oysters [13-15]. The $H$. ostrearia biotope has also been studied; it was demonstrated that: i) this diatom is extremely tolerant to high irradiance (thus offering an ecological advantage over the other main diatoms encountered in oyster ponds, e.g. Skeletonema costatum $[16,17])$; and ii) the greening phenomenon is controlled by the nutrient composition in oyster-pond waters (see [18] for conditions). Recently, a more detailed genetic characterization of $H$. ostrearia was undertaken by developing genetic molecular tools, which led to identifying new strains of $H$. ostrearia [19] along with a second species of blue diatom called Haslea karadagensis. 
Surprisingly, only a few studies have focused on bacteria-microalgae interactions, in noting that some bacteria may increase the microalgal biomass while offering potential applications in aquaculture. For now, nothing is still known for the specific case of $H$. ostrearia, yet for instances regarding bacteria and diatoms overall, "they have co-occurred in common habitats throughout the oceans for more than 200 million years, fostering interactions between these two groups over evolutionary time scales" [20]. The link between bacterioplankton and phytoplankton dynamics was recently demonstrated by Rooney-Varga et al. [21]. The habitat of phytoplankton-associated bacteria has been depicted by the concept of "phycosphere", i.e. the area around algal cells where bacteria feed on extracellular products of the algae [22]. The phycosphere is thus the aquatic analog of the rhizosphere in soil ecosystems and has direct implications for nutrient fluxes to and from algal cells. Bacteria-microalgae interactions have been studied for several diatom species, including Guinardia delicatula, Pseudonitizschia pugens, Thalassiosira rotula, Skeletonema costatum [23], Ditylum sp., Thalassiosira sp., Asterionella sp., Chaetoceros sp., Leptocylindrus sp., Coscinodiscus sp. [24], Pseudonitzschia multiseries [25] and Nitzschia microcephala [26]. Some of these common species are frequently encountered in oyster-pond waters and sediments [11, 18]. On the whole, the bacterial biodiversity of the phycosphere was shown to be limited in comparison to the complexity of bacterial assemblages in bulk seawater [24]. The structure of the bacterial community related to microalgae is specific to the microalgae species $[20,24,27]$, though some bacterial phylotypes, such as bacteroides, are known to play a significant role in nutrient cycling by degrading algal macromolecules; moreover, such species attach to growth and are then recovered in most phycospheres [28]. To demonstrate this specific bacterial-algal interaction, Schäfer et al. [24] attempted, using two algal cultures, to associate each culture with the "satellite" bacterial assemblage of the other culture and proved such an association infeasible. 
102 Based on these considerations, i.e. an incomplete knowledge of the ecological features of $H$. ostrearia, the present work has been intended to: i) characterize the structure of the bacterial community by means of PCR-TTGE both before and after $H$. ostrearia isolation from oyster ponds in different localities; ii) compare the bacterial community of the $H$. ostrearia phycosphere vs. free cells within the culture medium; iii) distinguish the relative portion of the biotope and biocenose based on the bacterial structure composition; and iv) describe the temporal dynamics of the bacterial community structure at the time scale of one culture cycle under laboratory conditions and after several subculturing steps. A metabolic fingerprinting (untargeted approach) was aimed at assessing the global metabolic profile of $H$. ostrearia cultures, whether or not associated with the phycosphere bacteria. Additional clarifications on the bacteria- $H$. ostrearia associations were provided, as well as on the role of the geographic origin of H. ostrearia. The compound class or classes potentially affected under these study conditions were not anticipated; moreover, specific compounds were not necessarily identified or quantified.

\section{Materials and methods}

\subsection{Sampling location}

The test samples were collected in oyster ponds from four localities along the French Atlantic coast, along the following north-to-south gradient: Bouin $\left(46.96^{\circ} \mathrm{N} ; 2.04^{\circ} \mathrm{W}\right)$, La Barre-deMonts $\left(46.90 \mathrm{~N} ; 2.11^{\circ} \mathrm{W}\right)$, Isle of Ré $\left(46.22 \mathrm{~N} ; 1.45^{\circ} \mathrm{W}\right)$, and La Tremblade $(45.80 \mathrm{~N}$; $1.15^{\circ} \mathrm{W}$ ) (see Fig. 1). One liter of each sample was collected at the seawater-sediment interface on the bottom of the oyster ponds in order to obtain both sediment and seawater. The samples were immediately stored at $4^{\circ} \mathrm{C}$. In the laboratory, the presence of $H$. ostrearia was verified before isolation. 


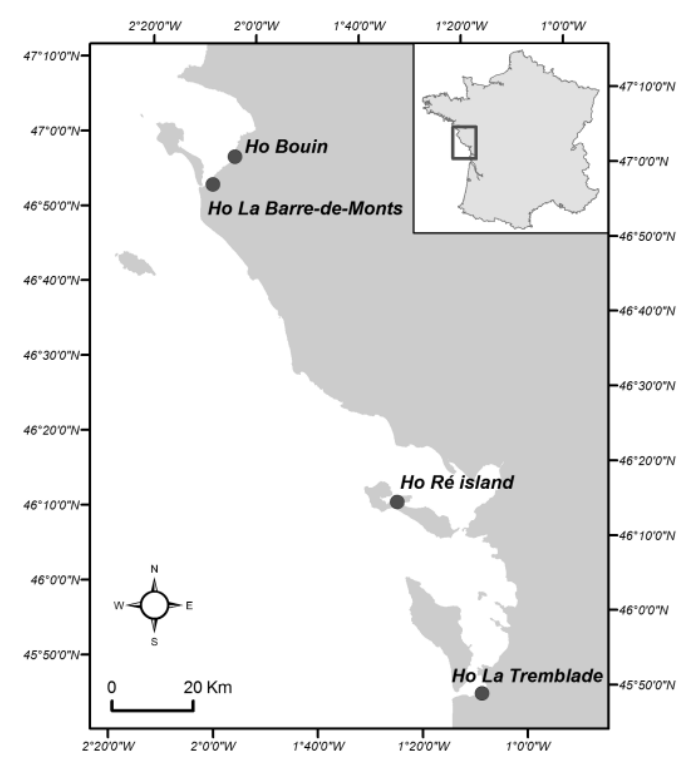

129

130

131

132

133

Fig. 1: Map of the French Atlantic coast showing oyster-pond locations where samples were collected to isolate Haslea ostrearia: Bouin $\left(46.96^{\circ} \mathrm{N} ; 2.04^{\circ} \mathrm{W}\right)$, La Barre-de-Monts $\left(46.90 \mathrm{~N} ; 2.11^{\circ} \mathrm{W}\right)$, Isle of Ré (46.22 N; $\left.1.45^{\circ} \mathrm{W}\right)$, and La Tremblade $\left(45.80 \mathrm{~N} ; 1.15^{\circ} \mathrm{W}\right)$.

\subsection{Isolation of $\boldsymbol{H}$. ostrearia from environmental samples and cultivation}

Monospecific cultures of $H$. ostrearia were obtained by isolating a single cell of $H$. ostrearia from the raw samples. The specimen was recovered using a capillary pipette and an inverted microscope; it was then washed by successive cell subculturing in filtered seawater $(0.22 \mu \mathrm{m})$ to remove contaminants (e.g. bacteria, other microalga, flagellate, larvae). Among the $H$. ostrearia isolates, six were selected for the following studies: $\mathrm{HO} 1$ and $\mathrm{HO} 2$ Bouin (HO1-B and HO2-B), HO La Barre-de-Monts (HO-BM), HO Isle of Ré (HO-R), and HO1 and HO2 La Tremblade (HO1-T and HO2-T).

For the ensuing experiments, the aforementioned isolates were grown in $250 \mathrm{~mL}$-Erlenmeyer flasks filled with $150 \mathrm{ml}$ of the modified Provasoli [29] medium (ES1/3: [30]) to obtain sufficient biomass. The monospecific isolates of $H$. ostrearia were transferred during the 
exponential growth stage (every 7-10 days) into a fresh ES 1/3 medium. The cultures were incubated in a culture chamber at $16^{\circ} \mathrm{C}$ under $120 \mu \mathrm{mol}$ photons $\mathrm{m}^{-2} \mathrm{~s}^{-1}$ and a 14:10 h light : dark regime.

\subsection{Algal fingerprints and the bacterial community structure}

\subsubsection{Sample preparation}

Raw sediments: The seawater and sediment of the raw samples recovered in the oyster ponds were separated by overnight sedimentation in a culture chamber at $16^{\circ} \mathrm{C}$. The samples were then frozen at $-20^{\circ}$ C. $0.5 \mathrm{~g}$ of sediment was used for DNA extraction purposes.

Supernatant and biofilm from monospecific H. ostrearia cultures: To compare the bacterial community structure in the algal biofilm, which entails comparing the bacteria embedded in exopolysaccharides forming biofilm and epiphytic bacteria of $H$. ostrearia with that of the suspended cells in the culture medium, the biofilm and supernatant from the culture of $H$. ostrearia were separated. From cultures during the exponential growth stage in $250-\mathrm{mL}$ Erlenmeyer flasks filled with $150 \mathrm{~mL}$ of ES $1 / 3$ medium, $100 \mathrm{~mL}$ of the liquid - attached at the bottom of the Erlenmeyer flasks - were carefully collected to avoid contact with the biofilm, and the few free alga (possibly associated with bacteria) were removed by centrifugation (SIGMA 3K30 Fisher Bioblock Scientific: $900 \mathrm{~g}, 90 \mathrm{~s}, 16^{\circ} \mathrm{C}$ ) to ensure recovering in the supernatant just the bacteria in suspension within the culture medium. The supernatant was filtrated through a $0.22-\mu \mathrm{m}$ filter (cellulose nitrate membrane, Sartorius) so as to concentrate the bacteria on the filter, which was then frozen at $-20^{\circ} \mathrm{C}$. Before DNA extraction, each filter was cut into small pieces of about $4 \mathrm{~mm}^{2}$.

From this same culture, the remaining $50 \mathrm{~mL}$ were eliminated, and $30 \mathrm{~mL}$ of fresh ES $1 / 3$ medium were added to the Erlenmeyer flask; the algal biofilm was recovered by means of the mechanical action of a sterile bar magnet. Microalgae and bacteria (epiphytic and those 
embedded in the biofilm) were both recovered by centrifugation (SIGMA 3K30 Fisher Bioblock Scientific: $6000 \mathrm{~g}, 5 \mathrm{~min}, 16^{\circ} \mathrm{C}$ ), and the samples were frozen at $-20^{\circ} \mathrm{C}$ prior to DNA extraction.

Cultures of $\mathrm{H}$. ostrearia at various growth stages and generations: For both experiments, approx. $1.5 \cdot 10^{6}$ algal cells were collected once the culture had been homogenized and then centrifuged (Universal 320 Hettich: $6000 \mathrm{~g}, 10 \mathrm{~min}, 16{ }^{\circ} \mathrm{C}$ ); the pellets containing suspended cells and cells of the biofilm were frozen at $-20^{\circ} \mathrm{C}$ prior to DNA extraction.

The bacterial community structures of the HO-BM and HO-R isolates were studied at the time scale of one culture cycle. Samples were collected at the time of transferring H. ostrearia into the fresh ES 1/3 medium after being isolated and cultured in the laboratory for one year (Day 0 ) and again after another 3, 7, 15 and 30 days.

The bacterial community structures of the HO-BM, HO-R, HO1-B, HO2-B, HO1-T and HO2$\mathrm{T}$ isolates were also studied at the time scale of various subculturings of $H$. ostrearia: $\mathrm{T} 0$, $\mathrm{T}+3, \mathrm{~T}+6$ and $\mathrm{T}+9$ months following $H$. ostrearia isolation. At each of these times, a biometric measurement (cell length) was conducted on 90-200 algal cells using an Olympus AX70 PROVIS microscope; final determination relied on the LUCIA G software.

Axenic and non-axenic $\mathrm{H}$. ostrearia cultures for metabolomic profiling: $\mathrm{HO}-\mathrm{BM}$ and $\mathrm{HO}-\mathrm{R}$ were cultivated in 250-mL Erlenmeyer flasks. The cells forming a biofilm at the bottom of the vessel were recovered during the exponential growth stage after being re-suspended with a sterile bar magnet, and homogenized and counted using a Nageotte chamber. Microalgae were then inoculated at $3 \cdot 10^{3}$ cells $\mathrm{mL}^{-1}$ (two replicates) in $100-\mathrm{mL}$ Erlenmeyer flasks containing fresh ES 1/3 medium and an antibiotic antimycotic solution (10,000 units penicillin, $10 \mathrm{mg}$ of streptomycin and $25 \mu \mathrm{g}$ of amphotericin $\mathrm{B} \mathrm{mL}^{-1}$, BioReagent, A5955 SIGMA) diluted at 1:50 or $1: 100$. The cultures were incubated in a culture chamber at $16^{\circ} \mathrm{C}$ under $120 \mu \mathrm{mol}$ photons $\mathrm{m}^{-2} \mathrm{~s}^{-1}$ and a 14:10 h light : dark regime. Treatment was carried out for 7 days, subsequent to 
which the culture supernatant was removed and the algal biofilm washed once with fresh ES $1 / 3$ medium to eliminate the antibiotics. The cells were re-suspended with a sterile bar magnet in $25-30 \mathrm{~mL}$ of fresh ES $1 / 3$ medium, and $5 \mathrm{~mL}$ were transferred into $250-\mathrm{mL}$ Erlenmeyer flasks filled with $150 \mathrm{~mL}$ of fresh ES 1/3 medium (triplicate). After 7 days of culture without antibiotic treatment, a second 7-day treatment was conducted with the same antibiotic antimycotic solution diluted to 1:50, followed by 7 days of culture without treatment. After the second treatment, the bacterial concentration was drastically reduced compared to the nonaxenic cultures. These cultures were thus called "axenic". Cells were collected during the exponential growth stage: $200 \mu \mathrm{L}$ of the supernatant of $\mathrm{HO}$ cultures were collected, filtered on $0.20-\mu \mathrm{m}$ PTFE membrane filters (Interchim) and frozen at $-80^{\circ} \mathrm{C}$ prior to fingerprint acquisition. For non-axenic H. ostrearia cultures, from the stock cultures of HO-BM and HO$\mathrm{R}$ during the exponential growth stage in $250-\mathrm{mL}$ Erlenmeyer flasks, microalgae were inoculated in triplicate in 24 well plates at $3 \cdot 10^{3}$ cells $\mathrm{mL}^{-1}$ to monitor daily algal growth by measuring the fluorescence of chlorophyll (BMG LabTech: 440; $680 \mathrm{~nm}$ ). Microalga were incubated under the same conditions as for the axenic H. ostrearia cultures. After 6 days of culture (during the exponential growth stage), $200 \mu \mathrm{L}$ of the culture supernatant were collected, filtered on $0.20-\mu \mathrm{m}$ PTFE membrane filters (Interchim) and frozen at $-80^{\circ} \mathrm{C}$ prior to fingerprint acquisition.

\subsubsection{Bacterial DNA extractions}

DNA from raw sediments, as well as from supernatant derived from monospecific $H$. ostrearia cultures and $H$. ostrearia cultures at different growth stages and generations, was extracted using a NucleoSpin ${ }^{\mathrm{TM}}$ soil kit (Macherey-Nagel, GmbH \& Co., Germany). In the specific case of the supernatant of $H$. ostrearia cultures at different growth stages and generations, the initial steps of sample grinding were performed with an MM400 Bead Beater 
(Retsch Germany) $(3 \times 30 \mathrm{sec}, 25 \mathrm{~Hz})$. For biofilms, DNA was extracted using a NucleoSpin ${ }^{\circledR}$ Tissue kit (Macherey-Nagel, GmbH \& Co., Germany). The first grinding step was executed with the Bead Beater $(1 \mathrm{~min}, 25 \mathrm{~Hz})$, then a pre-lysing step that included grinding $\left(56^{\circ} \mathrm{C}, 105\right.$ min; grinding, $10 \mathrm{sec}, 25 \mathrm{~Hz}$ every $30 \mathrm{~min}$ ) was applied according to manufacturer's recommendations; DNA concentrations were also measured (SPECTROstar Nano, BMG LABTECH LVi Plate, Germany).

\subsubsection{PCR amplification}

The V3 region of the 16S rRNA gene was amplified using the 357F-GC and 518R primers [31]. The PCR reaction mixture contained $0.6 \mathrm{ng} . \mu \mathrm{L}^{-1}$ of DNA template, $0.1 \mu \mathrm{mol} . \mathrm{L}^{-1}$ of each primer, $200 \mu \mathrm{mol} . \mathrm{L}^{-1}$ of $\mathrm{dNTP}, 0.012$ unit. $\mu \mathrm{L}^{-1}$ of Taq polymerase $1 \times$ reaction buffer, 2.5 mmol.L $\mathrm{L}^{-1}$ of $\mathrm{MgCl}_{2}$, and $500 \mathrm{ng} \cdot \mu \mathrm{L}^{-1}$ of bovine serum albumin and $5 \%(\mathrm{v} / \mathrm{v})$ of dimethylsulfoxide introduced into a $50-\mu \mathrm{L}$ final reaction volume. The following cycling conditions were used for bacterial amplification: 1 cycle at $95^{\circ} \mathrm{C}$ for $8 \mathrm{~min}$, followed by 7 cycles of $95^{\circ} \mathrm{C}$ for $30 \mathrm{~s}, 68^{\circ} \mathrm{C}\left(-1^{\circ} \mathrm{C} /\right.$ cycle $)$ for $30 \mathrm{~s}, 72^{\circ} \mathrm{C}$ for $50 \mathrm{~s}$, and 28 cycles at $95^{\circ} \mathrm{C}$ for $30 \mathrm{~s}, 62^{\circ} \mathrm{C}$ for $30 \mathrm{~s}, 72^{\circ} \mathrm{C}$ for $50 \mathrm{~s}$, and a final extension cycle at $72^{\circ} \mathrm{C}$ for $30 \mathrm{~min}(\mathrm{CFX} 96$ Touch $^{\mathrm{TM}}$, Thermal Cycler, Bio-Rad, U.S.).

\subsubsection{Temporal temperature gradient electrophoresis (TTGE) and fingerprint} acquisition

PCR products (from Section 2.3.3) were separated by their GC\% using a Temporal Temperature Gel Electrophoresis [32]. TTGE analyses were performed using a DCode ${ }^{\mathrm{TM}}$ System (Bio-Rad, U.S.). The 9.5\% polyacrylamide gel was composed of two parts: a top, urea-free "concentration" part (stacking gel) applied approx. $1 \mathrm{~cm}$ from the base of the wells upward; and a bottom "denaturation" part (resolving gel), at $8 \mathrm{~mol} . \mathrm{L}^{-1}$ urea. Fifteen 
microliters of PCR products were deposited into each well. Migration took place in $1.25 \times$ TAE for $750 \mathrm{~min}$ at $50 \mathrm{~V}$, with a temperature gradient from $65^{\circ}$ to $70^{\circ} \mathrm{C}$, i.e. $+0.4^{\circ} \mathrm{C}$ per hour. The gels were stained using GelRed ${ }^{\mathrm{TM}}$ (Biotium, U.S.) and then imaged under UV light (Molecular Imager ${ }^{\circledR G e l}$ Doc $^{\mathrm{TM}}$ XRSystem, Bio-Rad, U.S., along with Image Lab ${ }^{\mathrm{TM}}$ software).

\subsection{Untargeted metabolomic profiling}

UHPLC-ESI-QToF, through implementing a non-targeted analytical strategy via highresolution mass spectrometry (HRMS) [33], was used to detect small soluble extracellular target compounds produced by the bacteria and $H$. ostrearia recovered from the culture medium.

LC-TOF/MS analysis samples: aliquots $(5 \mu \mathrm{L})$ of each sample from the supernatant of $H$. ostrearia cultures (see Section 2.3.1.) were separated on a Kinetex, 1.7- $\mu \mathrm{m}$ C18 $100 \AA$ (Phenomenex) column $(150 \times 2.1 \mathrm{~mm})$ maintained at $40^{\circ} \mathrm{C}$, using an Agilent 1290 Infinity LC system with a gradient mobile phase $\left(0.5 \mathrm{~mL} \mathrm{~min}^{-1}\right)$ comprising $0.1 \%$ aqueous acetic acid (A) and acetonitrile containing $0.1 \%$ acetic acid (B). The gradient present was as follows: $5 \% \mathrm{~B}$ from 0 to $2.4 \mathrm{~min}$, increasing to $25 \% \mathrm{~B}$ from 2.4 to $4.5 \mathrm{~min}$, then raised to $30 \% \mathrm{~B}$ from 4.5 to $11 \mathrm{~min}$, finally reaching $100 \% \mathrm{~B}$ from 11 to $14 \mathrm{~min}$ and held there until $16.5 \mathrm{~min}$, followed by a decrease to 5\% B until 20 min have elapsed and then maintained at 5\% B until $25 \mathrm{~min}$. The eluent was directly introduced into the mass spectrometer by an electrospray. Mass spectrometry was conducted on a 6540 UHD Q-TOF mass spectrometer (Agilent Technologies, Waldbronn, Germany) operating in positive ion mode. The capillary voltage, fragmentor voltage and skimmer were set at 3,900, 150 and $60 \mathrm{~V}$, respectively. The sheath gas was measured at $350^{\circ} \mathrm{C}\left(12 \mathrm{~mL} \mathrm{~min}^{-1}\right)$ and the drying gas at $175^{\circ} \mathrm{C}\left(5 \mathrm{~mL} \mathrm{~min}^{-1}\right)$ with a 43 -psi nebulizer. Nitrogen was used as the collision gas. Mass spectra were acquired in a full scan analysis over an $\mathrm{m} / \mathrm{z}$ range of 50 - 1,700 using an extended dynamic range and a centroid 
mode of storage. The data station operating software was the MassHunter Workstation Software (version B.06).

\subsection{Experimental replication and data processing}

Experimental replication: For TTGE analysis, six samples followed by six distinct DNA extracts from the four studied localities were recovered from oyster ponds (Section 2.2), and their bacterial structures were compared (for raw sediments, biofilm and water column). A genetic comparison of $H$. ostrearia isolates was also carried out. To monitor the temporal dynamic of the bacterial community structure over the course of one algal culture cycle, experiments were replicated twice and moreover used to monitor this structure for its temporal dynamics during a 9-month serial subculturing campaign. For the non-targeted metabolomic investigation, analyses were carried out in triplicate.

Data processing: The 16S rRNA banding patterns on imaged TTGE gels were analyzed using the Molecular Analyst Fingerprinting software: FPQuestTM (Bio-Rad, U.S.). Put briefly, the software constructed a density profile through each lane and calculated the relative contribution of each band to the total band signal in a lane, after applying a rolling disc to serve as background subtraction. The banding patterns of the samples in each lane were compared with one another. The Unweighted Pair Group Method with Arithmetic Mean (UPGMA) was used to draw a dendrogram from similarity coefficients. To decrease the bias, we opted to analyze band patterns by exercising the densitometric-curve option, as previously used by Kuntz et al. [34] and Seghers et al. [35] instead of the band-detection option. For the metabolomic investigation, data were processed using the MassHunter Qualitative Analysis software (Agilent Technologies), with compounds being extracted from the raw data with the Molecular Feature Extraction (MFE) algorithm. Moreover, a principal component analysis 
was conducted using the Mass Profiler Professional B12.05 statistical package (also from Agilent Technologies).

\section{Results}

\subsection{Bacterial community structure of sediment samples from oyster ponds}

The structure of the bacterial community from oyster-pond bulk sediment samples varied depending on sampling location: Isle of Ré only showed 15\% similarity with other localities. In contrast, samples from the other localities displayed a similar bacterial community structure (i.e. $>85 \%$, see Fig. 2).

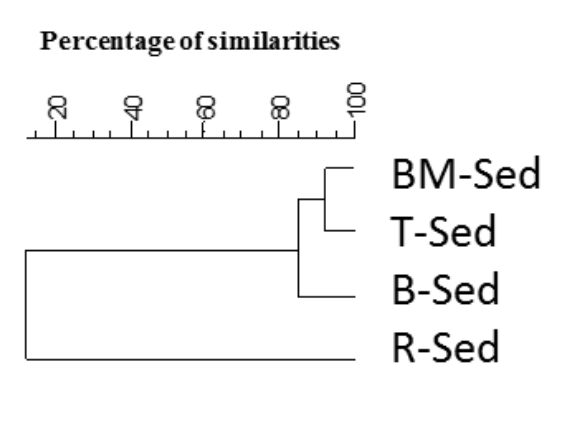

Fig. 2: Bacterial community structure of sediment samples (Sed) collected in oyster ponds from various localities (B: Bouin, BM: La Barre-de-Monts, R: Isle of Ré, T: La Tremblade)

\subsection{Community structure of bacteria recovered from the biofilm after Haslea} ostrearia isolation and from bacteria suspended in the water column

First of all, the structure of the bacterial community from the sediment compared to that of the biofilm after $H$. ostrearia isolation differed considerably (only $10 \%$ similarity between sediment and biofilm, data not shown). This result demonstrates that the bacteria associated with $H$. ostrearia were specific to the microalga.

Furthermore, a comparison of community structure of the bacteria recovered from the biofilm with those of the water column (WL), i.e. suspended bacterial cells (Fig. 3), revealed similarities that did not exceed $10 \%$. 
Percentage of similarities
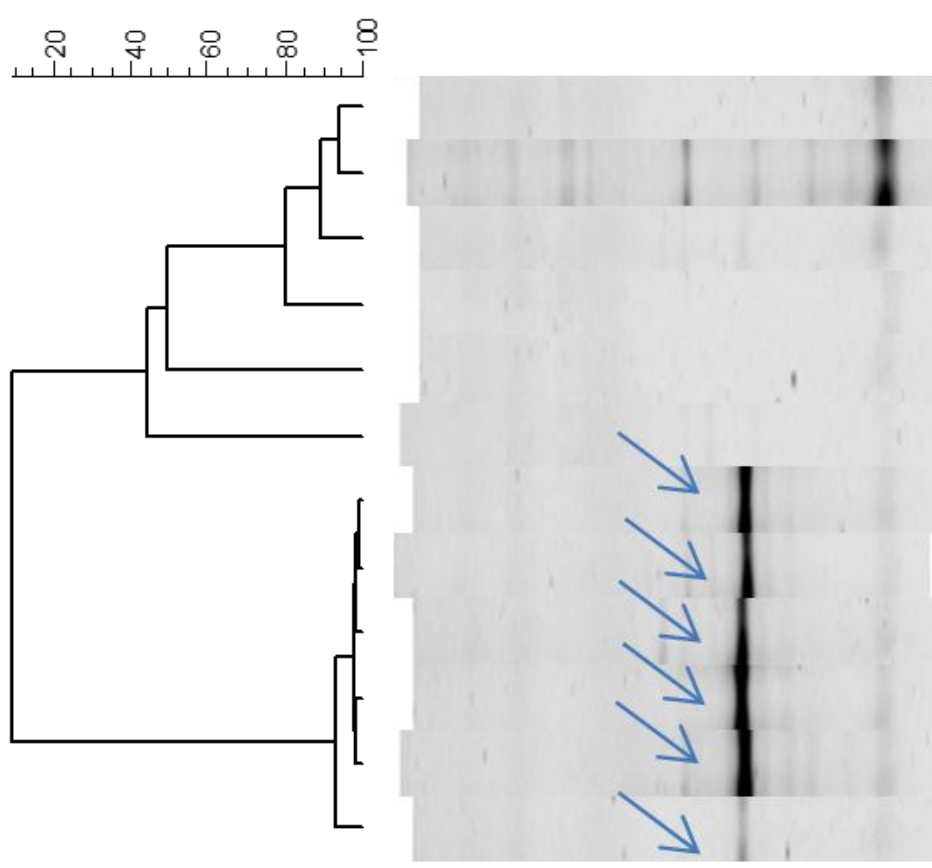

HO2-B-WL
HO2-T-WL
HO1-B-WL
HO-R-WL
HO-BM-WL
HO1-T-WL
HO-R-Biof
HO1-T-Biof
HO1-B-Biof
HO2-B-Biof
HO2-T-Biof
HO-BM-Biof

Fig. 3: TTGE analysis of the bacterial community structure from biofilm (Biof) and water column (WL) samples after isolation of $H$. ostrearia from various localities and subculturing in ES 1/3 medium under laboratory conditions (B: Bouin, BM: La Barre-de-Monts, R: Isle of Ré, T: La Tremblade). Arrows indicate the position of the band corresponding to the suspected chloroplastic and/or mitochondrial DNA of H. ostrearia.

With respect to the biofilm, the observed similarities in bacterial community structures exceeded $90 \%$ regardless of the geographic origin of the $H$. ostrearia isolates. The presence of a high-intensity band (see arrows in Fig. 3) was assumed to represent chloroplastic and/or mitochondrial DNA from $H$. ostrearia. The resulting phylogenetic tree with and without this band remained unchanged.

For the water column, similarities among the various algal isolates were more variable and

329 lower overall (e.g. only 40\% between HO1-T and HO2-B, extending to 95\% between HO2-B and $\mathrm{HO} 2-\mathrm{T})$. 

Barre de Monts and Isle of Ré

Two distinct $H$. ostrearia isolates were used for the metabolomic analysis, namely: HO-BM and HO-R. The number of total compounds was much lower in the so-called "axenic" $H$. ostrearia cultures, which account for algal compounds (Fig. 4a), compared to the non-axenic cultures encompassing both algal and bacterial compounds (Fig. 4b).
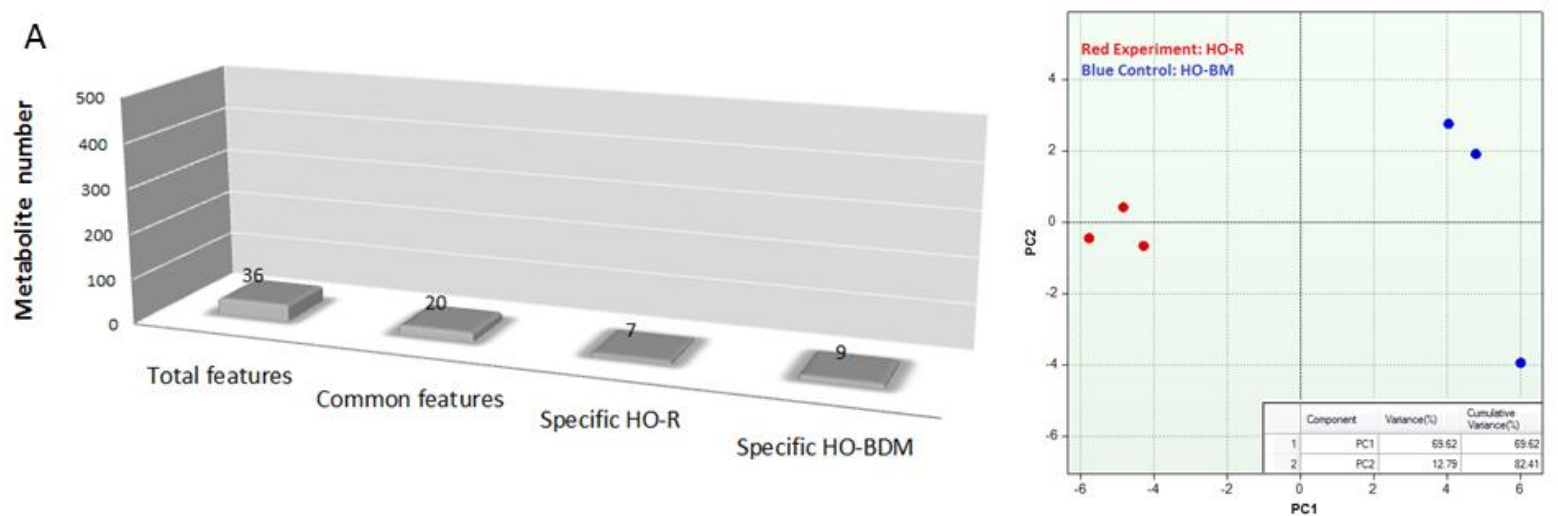

B
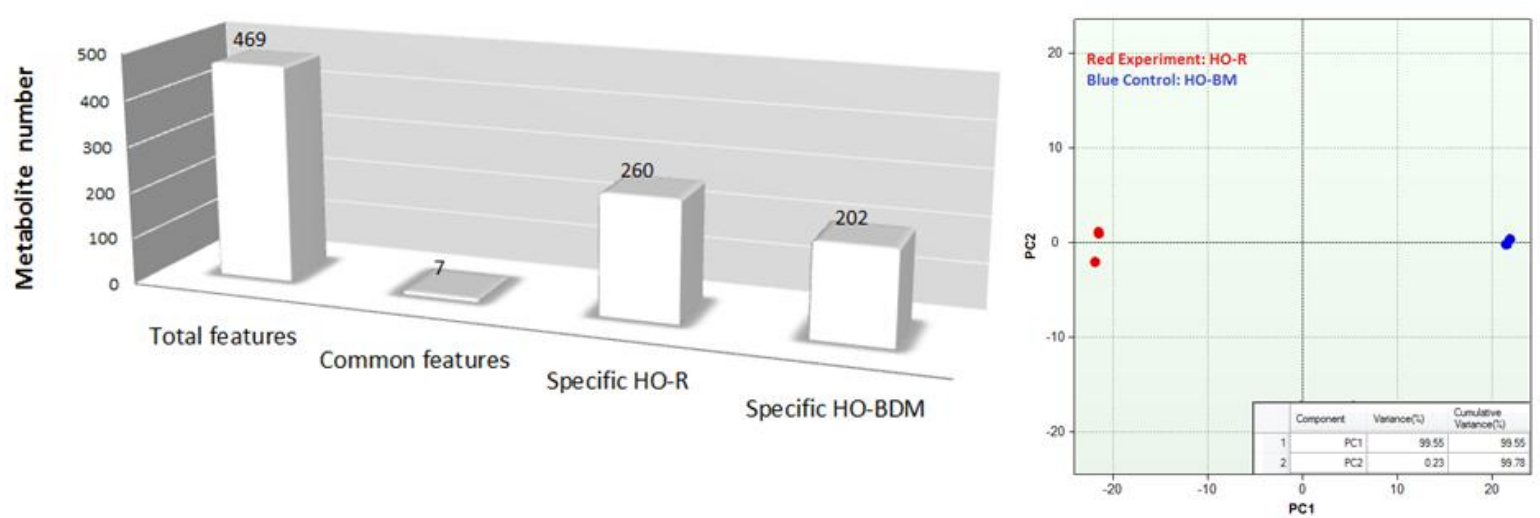

Fig. 4: Number of compounds recovered from HO-BM and HO-R isolate cultures (left) and the related principal component analysis representations (right) (in considering $\mathrm{p}<0.05$ and fold-change $>1.2$ ):

a) axenic; and b) non-axenic conditions. "Total", "common" and "specific" refers to the total compounds recovered, compounds shared by both isolates and compounds specific to each isolate, respectively. All analyses were performed in triplicate. 
Axenic conditions were associated with a high number of common compounds (20 out of 36)

350

351

352

353

354

355

356

357

and a small number of compounds specific to each isolate ( 7 and 9 for HO-R and HO-BM, respectively).

The opposite was exposed with non-axenic conditions, i.e. a low number of common compounds (7 out of 469), while 260 and 202 compounds were specific to HO-R and HO$\mathrm{BM}$, respectively.

In this instance, a Principal Component Analysis (PCA) approach to pattern recognition was used to distinguish the classes. Data from the control group (blue) and experimental group (red) were processed and a data matrix generated. Figures 4a and b display the 2D PCA score plot of the control group and experimental group under both axenic and non-axenic conditions. PCA analyses have confirmed that the differences in metabolic profiling between HO-R and HO-BM were more significant under non-axenic conditions than axenic conditions. The non-axenic model distribution points are indeed less dispersed $(99 \%$ of the variance explained by axis 1 of the PCA (PC1) under non-axenic conditions vs. just $69 \%$ under axenic conditions).

\subsection{Structure of the bacterial community from Haslea ostrearia isolates on two time} scales

\subsubsection{Over the course of one algal culture cycle}

This experiment, performed in duplicate with two H. ostrearia isolates (HO-BM and HO-R), found perfect repeatability of the TTGE analysis (Fig. 5). At the culture cycle scale, a marked evolution in the bacterial community could be observed. 

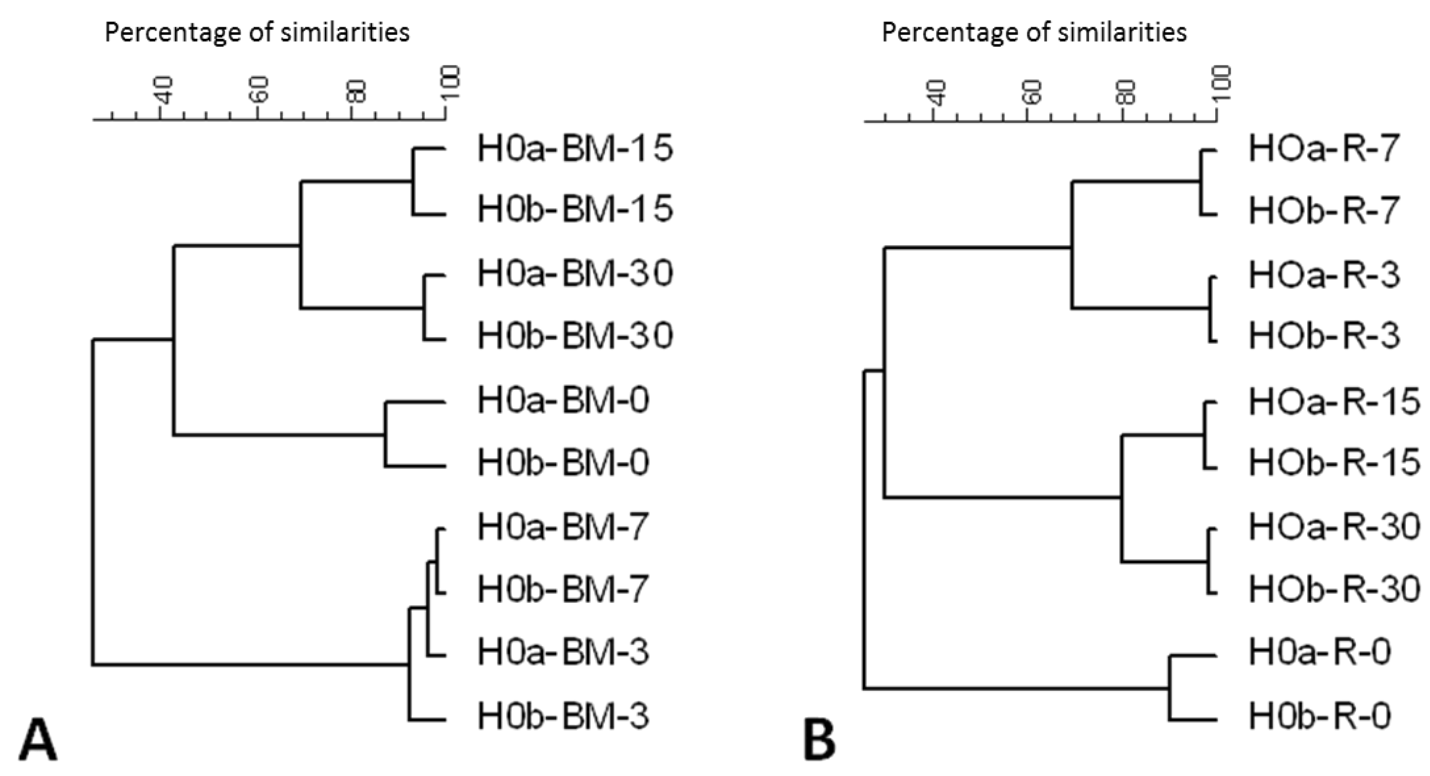

Fig. 5: Structure of the global bacterial community (suspension cells and biofilm cells) during a growth cycle of two Haslea ostrearia isolates (at days 0, 3, 7, 15 and 30): a) HO-BM: La Barre-deMonts, b) HO-R: Isle of Ré. Letters a and b stand for the two experimental replicates.

Three distinct clusters emerged, all of which were related to the algal growth stage: day 0 (initial bacterial community structure), days 3 and 7 (exponential phase), and days 15 and 30 (stationary phase and decline phase).

\subsubsection{Over a 9-month serial subculturing campaign}

Samples were recovered at the same growth stage, i.e. exponential. A rather low similarity in the bacterial structure was observed between $\mathrm{T} 0$ and the subsequent subculturing, irrespective of the algal isolate (Fig. 6): 25\% for HO-T, and 60\% similarity for HO-BM, HO-B and HO-R. This result demonstrates that once $H$. ostrearia was isolated and cultivated under laboratory conditions, the bacterial community structure evolved, but afterwards, i.e. from 3 to 9 months, the bacterial community structure was fairly stable regardless of isolate origin. Similarities in the bacterial community for each algal isolate during the 3- to 9-month period of culture did in fact top $70 \%$, with a maximum of $86 \%$ for $\mathrm{HO}-\mathrm{B}$. 


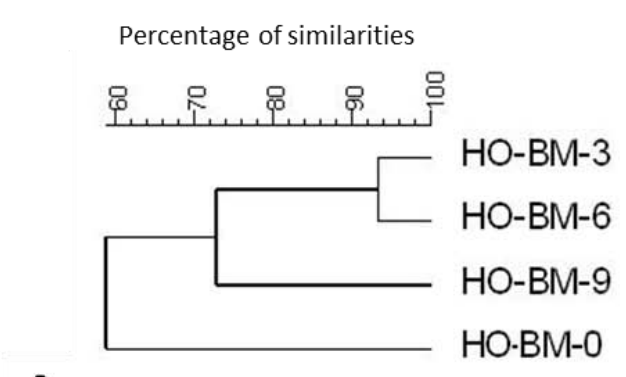

A

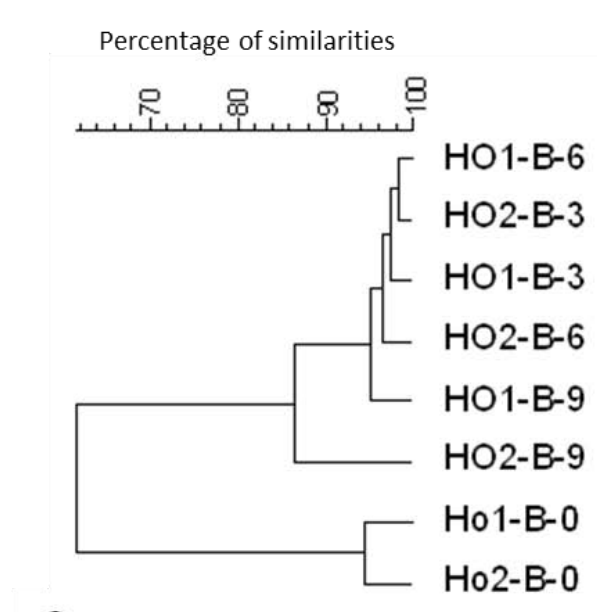

C

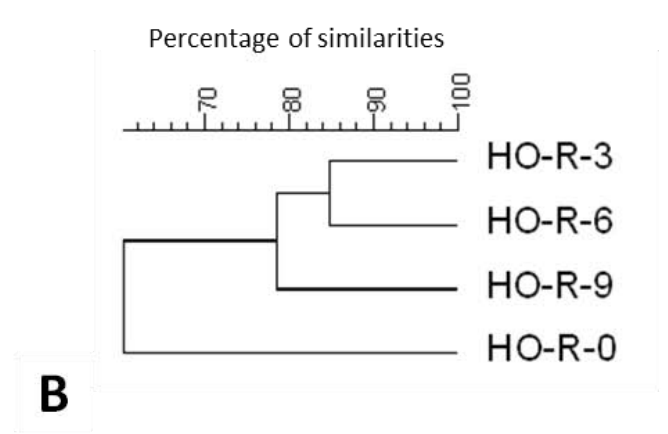

B

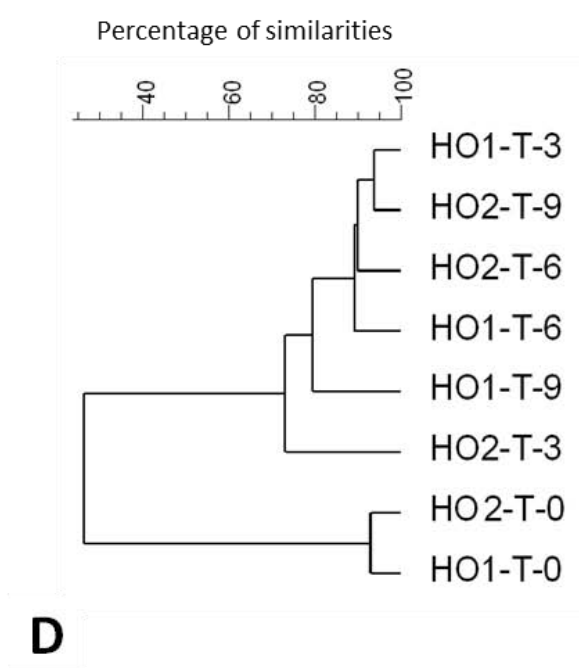

391

397

Fig. 6: TTGE analysis of the global bacterial community structure of Haslea ostrearia at the time of isolation (T-0) and after 3, 6 and 9 months of cultivation (T-3, T-6 and T-9, respectively). a) HO-BM: La Barre-de-Monts, b) HO-R: Isle of Ré, c) HO1-B and HO2-B: Bouin, d) HO1-T and HO2-T: La Tremblade.

For this pennate diatom, upon each cell division, the new valve is always formed within the parental theca, thus causing the average size of frustules in the population to slowly decrease. The size reduction in the $H$. ostrearia frustule, measured over the 9-month subculturing campaign (i.e. about $28.6 \% \pm 2.6 \%$, data not shown) exerted no influence on the bacterial community structure. 


\section{Discussion}

\subsection{Bacterial community structure of sediment samples from oyster ponds}

Except for the HO-R isolate, which displayed just a 15\% similarity with other isolates, strong similarities in bacterial structures were observed between isolates $(>85 \%$, Fig. 2), while the sampling locations are separated by up to 100 kilometers (Fig. 1), although their climatic conditions are similar. For HO-R, the relative dissimilarity is most likely due to the sampling depth, which was higher compared to the sampling conditions for other localities: not only was the sediment that deposited on the bottom of oyster ponds collected, but so was some underlying sediment constituting the bed of the oyster pond (specific physicochemical characteristics). We have thus postulated that the bacterial assemblage of the sediment deposited on the bottom of the ponds and the underlying sediment were distinct.

For other localities showing high levels of similarities, the specific characteristics and functioning of the oyster ponds could explain these results. These ecosystems are indeed managed by human beings for optimal oyster production. Nutrients (quality, amount) for oysters, as well as for all living oyster pond organisms including algae and bacteria, were most likely to be similar from one pond to another, as proven by Turpin et al. [18] for oyster ponds in the same areas as those studied herein.

Whether or not the oysters were present at the time of sampling (no oysters were found in the ponds of La Barre-de-Monts and Bouin; oysters were present in the ponds of La Tremblade and Isle of Ré) did not seem to influence the bacterial community structure. Since the pond management history is an unknown, it may be assumed that empty ponds were filled with oysters shortly before the sampling campaign and moreover that the seawater composition in these ponds remained unchanged in the meantime. 
Once $H$. ostrearia had been isolated from the sediment samples of the various localities, it culture medium, light, temperature).

Compared to the bacterial community structure in the bulk sediment, the structure relative to the phycosphere of $H$. ostrearia, i.e. epiphytic bacteria and those embedded in the biofilm, was very distinct with cross-sample similarities not exceeding $10 \%$ (data not shown). This result is typically observed in higher plants where the bacteria of the rhizosphere are compared to those of the bulk soil [36]. Regarding the TTGE pattern band numbers, it was surprising to note that they were higher for the biofilm samples than the bulk sediment samples. On the contrary, Schäfer et al. [24] observed that the bacterial biodiversity of the phycosphere was limited when compared to the complexity of bacterial assemblages in bulk seawater. Nonetheless, various results were shown when the rhizosphere bacteria were compared to bulk soil bacteria [36]. In our case, it can be assumed that the extracellular compounds of $H$. ostrearia are sufficiently diversified to support the growth of various bacterial populations. At least 36 (out of 469) compounds were indeed detected (Fig. 4) depending on whether H. ostrearia was axenic or not.

Irrespective of the geographic origin of the $H$. ostrearia samples, the bacterial structure of the

448 biofilm samples was found to be similar (Fig. 3), including the HO-R isolate, while the 449 bacterial structure of the sediment samples for this locality differed markedly (Fig. 2). This 450 result shows that the bacterial structure of the phycosphere is specific to H. ostrearia; it has 451 indeed been demonstrated that the structure of the bacterial community associated with the microalgal strain was specific to the microalgae [20, 24, 27]. For HO-R, it could then be 
concluded that the particular bacterial structure of the sample recovered from the sediment was solely influenced by the biotope characteristics, i.e. the specific sediment characteristics. The significant differences in the bacterial community structures between phycosphere bacteria and bulk water column bacteria (15\% similarity between the two groups, Fig. 3) confirm the significant effect of $H$ ostrearia in establishing a specific community hosted by the phycosphere. The highest level of bacterial structure similarity observed between biofilm samples ( $>90 \%$ ), as compared to $40 \%-90 \%$ for the suspended bacteria of the same samples, has also revealed the predominant role of $H$. ostrearia in establishing a bacterial structure specific to this species. The nutrient composition of $H$. ostrearia biofilms was, in all likelihood, very different from that of seawater, as the result of biofilm enrichment by algal exudates. The specificity of the bacterial community, with respect to algae in the environment where bacteria live, was previously presented by Eigemann et al. [37], who demonstrated that the influence of the algal host dominated the effect of changes in environmental conditions. Liu et al. [38] showed that the phytoplankton community succession influences changes in bacterial community composition. In the specific case of toxin production (like domoic acid) by algae, Sison-Mangus et al. [39] reported that the three tested Pseudo-nitzschia species, which vary in toxin production, had phylogenetically distinct bacterial communities and, moreover, that toxic Pseudo-nitzschia exhibited less microbial diversity than non-toxic Pseudo-nitzschia. Bruckner et al. [40] suggested an adaptation of Proteobacteria and Bacteroidetes in the microenvironment created by the diatom biofilm. For the suspended bacteria in the water column, the varying geographic origins of the samples, which very probably reveal differences - even slight - in biotope characteristics, likely explains the differences in bacterial structures given that they were not under the direct influence of $H$. ostrearia. 
Regarding the two isolates of La Tremblade (HO1-T and HO2-T), the limited similarity of the suspended bacterial cell structures (40\%, Fig. 3) might be the result of initially different bacterial structures that did not converge after $H$. ostrearia isolation, in contrast with what was observed for the biofilm ( $>95 \%)$ due to the considerable influence of exudation.

\subsection{Metabolic profiles of HO-R and HO-BM}

One of the greatest differences in the bacterial community structure was shown for HO-BM and HO-R isolates in both the biofilm and water column (Fig. 3); this finding may be explained by differences in the metabolic profiles (Fig. 4). The axenic cultures of H. ostrearia indeed display distinguishable metabolomes (Fig. 4a), though their differences remain minimal: 20 compounds in common out of 36 , which is not surprising since the biometric analysis of the isolates by scanning electron microscopy (SEM), based on the density of transapical and longitudinal striations of the frustule, indicates that they belong to the $H$. ostrearia species.

To access the bacterial metabolom, it might have been tempting to subtract the number of compounds of the axenic treatment (Fig. 4a) from the number of the xenic compounds (Fig. 4b). Extreme care must be exercised however since some bacteria-microalgae interactions cannot be excluded. Bacteria and microalgae probably exhibit different metabolic profiles depending on whether $H$. ostrearia is cultivated as a monoculture or in association with the phycosphere bacteria. It should still be noted that the metabolic profile of the bacteria- $H$. ostrearia association is very specific to HO-R and HO-BM, with just 7 common compounds out of 469 .

It cannot be overlooked that a few compounds were not those produced by the alga and/or bacteria, but instead compounds of other organisms since the culture medium (ES 1/3) consists of filtered (to $0.2 \mu \mathrm{m}$ ) seawater enriched with minerals. We have assumed that 
medium sterilization degraded nearly all of the remaining compounds. The seawater used to prepare the culture medium was the same for cultivating the two isolates, thus avoiding any bias resulting from possible geographic differences.

\subsection{Structures of the bacterial community from Haslea ostrearia isolates on two} time scales

At the culture cycle scale (i.e. one to two weeks), the changes in bacterial community structure (Fig. 5) were related to the various growth stages of $H$. ostrearia, i.e. lag time, exponential growth stage and stationary stage, most likely as a result of exudates in varying quantities and compositions. This phenomenon is well documented for bacteria growing in the rhizosphere of plants [41]. At the seasonal time scale, Liu et al. [38] demonstrated that phytoplankton community succession influences the bacterial community composition.

The change in bacterial community structure is cyclical. When H. ostrearia was sampled at the same (exponential) growth stage over a nine-month period (i.e. 30 subculturings), the bacterial community structure remained quite stable ( $75 \%$ to $85 \%$ similarity between 3 and 9 months, see Fig. 6). It can be assumed that the entire bacterial community associated with $H$. ostrearia (embedded, epiphytic and free bacteria) was transmitted at each subculturing. The decrease in the frustule size of diatoms, already witnessed for H. ostrearia [42], did not alter the bacterial structure even though the algal size of some isolates at the end of the experiment (between 52 and $82 \mu \mathrm{m}$, with an average of $61.2 \mu \mathrm{m}$ ) was in the range for auxosporulation (i.e. between 50 and $68 \mu \mathrm{m}[43,44])$.

Between the first subculturing (T-0) and the third month, the bacterial structure changed significantly (25\% to $60 \%$ similarity) as the result of the bacterial community adapting to the maintenance culture conditions with stabilization after 3 months due to the well-controlled conditions for the culture of $H$. ostrearia isolates. This finding suggests that the laboratory 
conditions for H. ostrearia (culture medium composition, temperature, light) also influence the composition of the bacterial assemblage, as demonstrated by Sapp et al. [45]; these authors found a shift in the bacterial populations associated with diatoms between isolation and cultivation of algal cells, with an increase in the number of phylotypes belonging to Gammaproteobacteria members.

\section{Conclusion}

For the first time, this study has analyzed the bacterial ecosystem surrounding the marine diatom $H$. ostrearia and showed that this bacterial structure is specific to the geographic origin of the microalgal isolate. Under laboratory conditions, once $H$. ostrearia has been isolated from oyster ponds, the bacterial community structure was shown to be resilient over a 9-month subculturing despite structural changes at the culture time scale according to the growth stage. Similarly, the differences in bacterial structures of two H. ostrearia isolates (HO-R and HO-BM) gave rise to specific metabolomic profiles. These profiles were more distinct with non-axenic microalgae, i.e. with inclusion of their associated bacteria, than with axenic microalgae, thus suggesting reciprocal relationships between bacteria and $H$. ostrearia cells.

\section{References}

[1] R. Gastineau, N. Davidovich, G. Hansen, J. Rines, A. Wulff, I. Kaczmarska, G. Carrier, Halea ostrearia-like Diatoms: Biodiversity out of the Blue. In Advances in Botanical Research: sea plant (2014) pp. 441-465.

[2] R. Simonsen, The diatom plankton of the Indian Ocean expedition of RV" Meteor" 19641965. Gebrüder Borntraeger (1974). 
552

553

554

555

556

557

558

559

560

561

562

563

564

565

566

567

568

569

570

571

572

573

574

[3] Ranson G, L'absorption de matières organiques dissoutes par la surface extérieure du corps chez les animaux aquatiques, Ann. Inst. Oceanogr. 4 (1927) 49-174.

[4] J.P. Bergé, N. Bourgougnon, S. Alban, F. Pojer, S. Billaudel, J.C. Chermann, G. Franz, Antiviral and anticoagulant activities of a water-soluble fraction of the marine diatom Haslea ostrearia, Planta medica 65 (1999) 604-609.

[5] R. Gastineau, J.B. Pouvreau, C. Hellio, M. Morançais, J. Fleurence, P. Gaudin, N. Bourgougnon, J.L. Mouget, Biological activities of purified marennine, the blue pigment produced by the diatom Haslea ostrearia and responsible for the greening of oysters, J. Agric. Food Chem. 60 (2012b) 3599-3605.

[6] J. B.Pouvreau, M. Morançais, F. Taran, P. Rosa, L. Dufossé, F. Guérard, S. Pin, J. Fleurence, P. Pondaven, Antioxidant and free radical scavenging properties of marennine, a blue-green polyphenolic pigment from the diatom Haslea ostrearia (Gaillon/Bory) Simonsen responsible for the natural greening of cultured oysters, J. Agric. Food Chem. 56 (2008) 62786286.

[7] T. Lebeau, P. Gaudin, G.A. Junter, L. Mignot, J.M. Robert, Continuous marennin production by agar-entrapped Haslea ostrearia using a tubular photobioreactor with internal illumination, Appl. microbiol. biotechnol. 54 (2000) 634-640.

[8] T. Lebeau, P. Gaudin, R. Moan, J.M. Robert, A new photobioreactor for continuous marennin production with a marine diatom: influence of the light intensity and the immobilisedcell matrix (alginate beads or agar layer), Appl. Microbiol. Biotechnol. 59 (2002) 153-159.

[9] N. Rossignol, T. Lebeau, P. Jaouen, J. M. Robert, Comparison of a two membrane photobioreactors, with free or immobilized cells, for the production of pigments by a marine diatom, Bioproc. Eng. 23 (2000a) 495-501. 
575 [10] N. Rossignol, P. Jaouen, J.M. Robert, F. Quéméneur, Production of exocellular pigment 576 by the marine diatom Haslea ostrearia Simonsen in a photobioreactor equipped with im577 mersed ultrafiltration membranes, Bioresour. Technol. 73 (2000b) 197-200.

578 [11] J. M. Robert, Fertilité des eaux des claires ostréicoles et verdissement: utilisation de 579 l'azote pas les diatomées dominantes. PhD thesis, University of Nantes, (1983) 281 pp.

580 [12] C. Sauvageau, A propos de la présence de la diatomée bleue dans la Méditerranée. Travaux des laboratoires (Arcachon), 6 (1906) 46-59.

582 [13] L. Barillé, J. Haure, E. Pales-Espinosa, M. Morançais, Finding new diatoms for intensive rearing of the pacific oyster (Crassostrea gigas): energy budget as a selective tool, Aquaculture 217 (2003) 501-514.

[14] B. Cognie, Alimentation de l'huître Crassostrea gigas (Thumberg): étude des mécanismes de sélection des particules et des processus rétroactifs entre le bivalve et les microalgues. PhD Thesis, University of Nantes (France), (2001) 166 pp.

[15] F. Piveteau, Etude des arômes de l'huître creuse Crassostrea gigas : conséquences d'un affinage à l'aide des microalgues Skeletonema costatum et Haslea ostrearia. PhD Thesis, University of Nantes (France), (1999) 213 pp.

[16] J.L. Mouget, G. Tremblin, A. Morant-Manceau, M. Morançais, J.M. Robert, Long-term photoacclimation of Haslea ostrearia (Bacillariophyta): effect of irradiance on growth rates, pigment content and photosynthesis, Eur. J. Phycol. 34 (1999) 109-115.

[17] G. Tremblin, R. Cannuel, J.L. Mouget, M. Rech, J.M. Robert, Change in light quality due to a blue-green pigment, marennine, released in oyster-ponds: effect on growth and photosynthesis in two diatoms, Haslea ostrearia and Skeletonema costatum, J. Appl. Phycol. 12 (2000) $557-566$.

[18] V. Turpin, Etude des événements physico-chimiques et biologiques présidant à la prolifération d'Haslea ostrearia (Simonsen) dans les claires ostréicoles de la région de Marennes- 
600 Oléron: implications dans la maîtrise du verdissement. PhD Thesis, University of Nantes 601 (France), (1999) 208 pp.

602

[19] R.Gastineau, N.A. Davidovich, J.F. Bardeau, O.I. Davidovich, Y. Rincé, P. Gaudin, E.J.

603

604

605

606

607

608

609

610

611

612

613

614

615

616

617

618

619

620

621

622

623

624

Cox, J.L. Mouget, Haslea karadagensis sp. nov. (Bacillariophyta), a new diatom from the

Black Sea producing a novel blue pigment, Eur. J. Phycol. 47 (2012a) 469-479.

[20] S. A. Amin, M.S. Parker, E.V. Armbrust, Interactions between diatoms and bacteria, Microbiol. Mol. Biol. Rev. 76 (2012) 667-684.

[21] J.N. Rooney-Varga, M.W. Giewat, M.C. Savin, S. Sood, M. LeGresley J.L. Martin, Links between phytoplankton and bacterial community dynamics in a coastal marine environment, Microb. Ecol. 49 (2005) 163-175.

[22] W. Bell, R. Mitchell, Chemotactic and growth responses of marine bacteria to algal extracellular products, Biol. Bull. 143 (1972) 265-277.

[23] M. Sapp, A.S. Schwaderer, K.H. Wiltshire, H.G. Hoppe, G. Gerdts, A. Wichels, Speciesspecific bacterial communities in the phycosphere of microalgae? Microb. Ecol. 53 (2007a) 683-699.

[24] H. Schäfer, B. Abbas, H. Witte, G. Muyzer, Genetic diversity of 'satellite' bacteria present in cultures of marine diatoms, FEMS Microbiol. Ecol. 42 (2002) 25-35.

[25] M.L. Guannel, M.C. Horner-Devine, G. Rocap, Bacterial community composition differs with species and toxigenicity of the diatom Pseudo-nitzschia, Aquat. Microb. Ecol. 64 (2011) 117-133.

[26] D. Schwenk, L. Nohynek, H. Rischer, Algae-bacteria association inferred by 16S rDNA similarity in established microalgae cultures, Microbiology Open 3 (2014) 356-368.

[27] A. M. Lakaniemi, C.J. Hulatt, K.D. Wakeman, D.N. Thomas, J.A. Puhakka, Eukaryotic and prokaryotic microbial communities during microalgal biomass production, Bioresour. technol. 124 (2012) 387-393. 
625 [28] R. Ramanan, Z. Kang, B.H. Kim, D.H. Cho, L. Jin, H.M. Oh, H.S. Kim, Phycosphere 626 bacterial diversity in green algae reveals an apparent similarity across habitats, Algal Res. 8 $627 \quad(2015)$ 140-144.

628 [29] L. Provasoli, Media and prospects for the cultivation of marine algae. In Cultures and 629 Collections of Algae. Proceedings of the US-Japan Conference, Hakone, September 1966, 630 (1968) pp. 63-75.

631 [30] T. Lebeau, G.A. Junter, T. Jouenne, J.M. Robert, Marennine production by agar632 entrapped Haslea ostrearia Simonsen, Bioresour. Technol. 67 (1999) 13-17.

633 [31] E. Jaffrès, D. Sohier, F. Leroi, M.F. Pilet, H. Prévost, J.J. Joffraud, X. Dousset, Study of 634 the bacterial ecosystem in tropical cooked and peeled shrimps using a polyphasic approach, Int J Food Microbiol 131 (2009) 20-29.

[32] G. Muyzer, K. Smalla, Application of denaturing gradient gel electrophoresis (DGGE) and temperature gradient gel electrophoresis(TGGE) in microbial ecology, Antonie van Leeuwenhoek 73 (1998) 127-141.

[33] F. Mondeguer, J.P. Antignac, Y. Guitton, F. Monteau, S. Le Borgne, P. Hess, Nouvelle stratégie de caractérisation non ciblée de type métabolomique au service de l'identification de composés bioactifs accumulés dans les mollusques bivalves, Spectra Analyse (2012) 24-33.

[34] J. Kuntz, N. Nassr-Amellal, M. Lollier, J. E. Schmidt, T. Lebeau, Effect of sludges on bacteria in agricultural soil. Analysis at laboratory and outdoor lysimeter scale. Ecotoxicology and Environmental Safety, 69(2) (2008) 277-288.

[35] D. Seghers, S.D. Siciliano, E.M. Top, W. Verstraete, Combined effect of fertilizer and herbicide applications on the abundance, community structure and performance of the soil methanotrophic community. Soil Biol. Biochem., 37 (2005), 187-193.

[36] A.D. Kent, E.W. Triplett, Microbial communities and their interactions in soil and 
650

651

652

653

654

655

656

657

658

659

660

661

662

663

664

665

666

667

668

669

670

671

672

673

674

rhizosphere ecosystems, Annu. Rev. Microbiol. 56 (2002) 211-236.

[37] F. Eigemann, S. Hilt, I. Salka, H.P. Grossart, Bacterial community composition associated with freshwater algae: species specificity vs. dependency on environmental conditions and source community, FEMS Microbial. Ecol. 83 (2013) 650-663.

[38] L. Liu, J. Yang, H. Lv, Z. Yu, Synchronous dynamics and correlations between bacteria and phytoplankton in a subtropical drinking water reservoir, FEMS Microbiol. Ecol. 90 (2014) 126-138.

[39] M.P. Sison-Mangus, S. Jiang, K.N. Tran, R.M. Kudela, Host-specific adaptation governs the interaction of the marine diatom, Pseudo-nitzschia and their microbiota, ISME J. 8 (2014) $63-76$.

[40] C.G. Bruckner, R. Bahulikar, M. Rahalkar, B. Schink, P.G. Kroth, Bacteria associated with benthic diatoms from Lake Constance: phylogeny and influences on diatom growth and secretion of extracellular polymeric substances. Appl. Environ. Microbiol. 74 (2008) 77407749.

[41] N.C. Uren, Types, amounts, and possible functions of compounds released into the rhizosphere by soil-grown plants. In: Pinton R, Varanini Z, Nannipieri P (eds) The rhizosphere: biochemistry and organic substances at the soil-plant interface. Marcel Dekker, New York (2000) pp. 19-40.

[42] P. Gaudin, T. Lebeau, J.M. Robert, Microalgal cell immobilization applied to the longterm storage of the diatom Haslea ostrearia, J Appl Phycol 18 (2006) 175-184.

[43] D. Neuville, P. Daste, Observations préliminaires concernant l'auxosporulation chez la diatomée Navicula ostrearia (Gaillon) Bory en culture in vitro, C. r. hebd. séances Acad. sci., (1975) 1753-1756

[44] N. A. Davidovitch,J. L. Mouget, P. Gaudin, Heterothallism in the pennate diatom Haslea ostrearia (Bacillariophyta), Eur. J. Phycol. 44(2) (2009) 251-261. 
675 [45] M. Sapp, A. Wichels, G. Gerds, Impacts of cultivation of marine diatoms on the associat676 ed bacterial community, Appl Environ Microbiol. 73 (2007b) 3117-3120. 